\title{
Spinal Cord Neuroblasts Proliferate in Response to Basic Fibroblast Growth Factor
}

\author{
Jasodhara Ray and Fred H. Gage \\ Department of Neurosciences, University of California San Diego, La Jolla, California 92093-0627
}

Trophic factors may function as one of the epigenic signals responsible for the proliferation, growth, migration, and differentiation of neurons and glia during embryogenesis. The present study reports that basic fibroblast growth factor (bFGF) at high concentrations (10-100 $\mathrm{ng} / \mathrm{ml})$ is a mitogen for embryonic spinal cord cells that have already committed to a neuronal pathway and are expressing neuronal phenotypes (neuroblasts). Neuroblasts proliferate with a doubling time of $\mathbf{2 . 5} \mathrm{d}$. To characterize the nature of cells proliferating in response to bFGF, we have established long-term cultures of neuroblasts that can be passaged, freeze thawed, and recultured. In cultures the proportion of astrocytes remained the same, indicating limited survival and proliferation of these cells in response to bFGF. These results indicate that bFGF has mitogenic effects preferably on neuroblasts. The morphological and biochemical characterizations of the neuronal populations present in the long-term neuroblast cultures are presented here. The presence of cholinergic and GABAergic neurons in the cultures was established by immunocytochemical analysis. The cultures contain a small number of motoneurons as judged by their immunostaining with ChAT, low-affinity NGF receptor (LNGFR), and large size. Among all other growth factors tested for their mitogenic effects on embryonic spinal cord cells in culture, only epidermal growth factor (EGF) showed such effects, but to a lesser degree. The proliferative nature of neuroblasts has made it possible to transduce the Escherichia coli $\beta$-galactosidase (LacZ) gene stably into these cells in vitro using a retroviral vector. The transfected cells expressing the foreign gene can be passaged, freeze thawed, and recultured without the loss of transgenes. The ability to transduce foreign genes stably into these cells permits implantation of these cells in the spinal cord to study cellular and biochemical behaviors and gene expression in defined neuronal populations in in vivo environments.

[Key words: basic fibroblast growth factor, spinal cord neuroblasts, proliferation of neuroblasts, perpetual neuronal cultures, stable gene transfer]

\footnotetext{
Received Aug. 30, 1993; revised Nov. 30, 1993; accepted Dec. 9, 1993.

We thank M. L. Gage for help in preparation of the manuscript; Dr. A. Tobin, University of California Los Angeles, for the generous gift of anti-GAD 67 antibody; Dr. Richard Mulligan, Whitehead Institute, Boston, MA, for MFG- $\beta$-gal vector; Drs. G. Chalmers and D. Peterson for help with the confocal microscopy; and Drs. L. J. Fisher, G. Chalmers, and H. Raymon for critical review of the manuscript. This work was supported by grants from the Hollfelder Foundation, NIH (POI AG10435, RO1 AG06088), and the Margaret A. and Herbert Hoover Foundation.

Correspondence should be addressed to F. H. Gage at the above address.

Copyright $\odot 1994$ Society for Neuroscience $0270-6474 / 94 / 143548-17 \$ 05.00 / 0$
}

During embryogenesis, neuroepithelial cells of the neural tube proliferate and give rise to different populations of neurons, astrocytes, and oligodendrocytes. The fate of a cell during neurogenesis has been determined by cell lineage studies (Sanes et al., 1986; Price et al., 1987; Luskin et al., 1988, 1993; Price and Thurlow, 1988; Williams et al., 1991; Stemple and Anderson, 1992; Kilpatrick and Bartlett, 1993), which have reported that glial and neuronal lineages have diverged at a very early stage of development (E10-E12 for mouse cortex and E10 for mouse mesencephalon, E12 for rat cortex). Most of the cells are committed by these stages of development, but a small portion of cells are multipotent. The multipotent cells that are capable of self-renewal and generating multipotent progeny are stem cells (Stemple and Anderson, 1992). Multipotent cells that are not capable of self-renewal and generate clonal progenies that give rise to neurons or glia are precursor/progenitor cells (Reynolds et al., 1992; Stemple and Anderson, 1992; Kilpatrick and Bartlett, 1993). Matured neurons and glial cells are not generated directly from precursor/progenitor cells but go through intermediate cell types, neuroblasts or glioblasts, but the existence of these cells is speculative. These studies raise the question of what factors channel these cells into different pathways. Although the precise nature of these factors is largely unknown, a number of trophic and tropic factors may control these processes during the development of the CNS.

The pathways for the generation of glial cells have been well studied (Raff, 1989), but the pathways that lead to the generation of neurons from precursor cells is not well understood. Growth factors have been reported to play an important role in generation of different forms of astrocytes from their precursor/progenitor cells or glioblasts. In vitro experiments have shown that type 1 astrocytes secrete growth factors that keep O-2A cells proliferating in cultures and prevent their premature differentiation (Noble and Murry, 1984). Platelet-derived growth factor has been identified as the crucial growth factor that type 1 astrocytes secrete to stimulate O-2A cell proliferation (Noble et al., 1988). Ciliary neurotrophic factor promotes the differentiation of bipotential O-2A progenitor cells into type 2 astrocytes (Hughes et al., 1988). The roles of growth factors on proliferation and differentiation of neuronal cells and their channeling into different neuronal populations during development are not well defined. A number of growth factors including families of nerve growth factors and fibroblast growth factors have becn reported to have survival effects on neurons in culture (Walicke et al., 1986, i988; Unsicker et al., 1987; Hartikka and Hefti, 1988; Alderson et al., 1990; Ip et al., 1993). The proliferative effects of mitogenic growth factors, basic fibroblast growth factor (bFGF) and epidermal growth factor (EGF), on neuroblasts or precursor/progenitor cells cultured from embryonic rat or mouse CNS 
have been reported (Gensburger et al., 1987; Murphy et al., 1990; Deloulme et al., 1991; Drago et al., 1991).

Basic FGF is expressed in early embryonic development and may play an important role in embryogenesis (Liu and Nicoll, 1988; Gonzales et al., 1990). The expression of high-affinity bFGF receptor mRNA in the CNS is developmentally regulated, and in embryos it is mainly localized in the ependymal layer of the CNS, which contains mitotic prccursor cclls (Wanaka ct al., 1991). This finding may suggest that in early embryo, bFGF exerts effects on mitotic undifferentiated precursor cells in the CNS. Short-term proliferative effects of bFGF on neuronal precursor/progenitor cells or neuroblasts cultured from different regions of rat and mouse CNS, including the spinal cord, have been reported (Gensburger et al., 1987; Murphy et al., 1990; Deloulme et al., 1991; Drago et al., 1991). The precursor cells from brain proliferated for $5 \mathrm{~d}$ and from spinal cord during the first $2 \mathrm{~d}$ after plating (Gensburger et al., 1987; Deloulme et al., 1991). These cultures were maintained for up to $8 \mathrm{~d}$ and the number of astrocytes in these cultures remained low $(<5-10 \%)$. Long-term proliferative effects of bFGF on embryonic hippocampal neuronal cells have been reported (Ray et al., 1993). These cultures did not contain any glial fibrillary acidic protein (GFAP)-positive astrocytes as determined by immunostaining with anti-GFAP antibody. Therefore, it may be concluded that bFGF is a mitogen preferably affecting the proliferation of neuroblasts in serum-free culture conditions. Another mitogenic growth factor, EGF, has proliferation and differentiation effects on precursor/progenitor cells of adult and embryonic mouse striatum in vitro (Reynolds and Weiss, 1992; Reynolds et al., 1992). These cells represented only a small $(<1 \%)$ portion of the total cell population and preferentially gave rise to glia. However, bFGF had no mitogenic effect on these cells. These results may suggest that different cell populations respond to different growth factors.

The complexity of the in vivo system makes it difficult to study the factors that may control generation of stem and precursor/progenitor cells and the subsequent differentiation of the latter cell population into neuroblasts and glioblasts and eventually to neurons and glia. Some of these controlling factors have been studied in in vitro systems using short-term cultures. Establishment of short-term cultures necessitates frequent dissection of tissues and cells can be followed for only a short period of time. Establishment of long-term cultures not only overcomes some of these difficulties but also provides more defined cultures, as variability in cultures generated from different dissections can be eliminated. The proliferative effects of bFGF on neuroblasts have been utilized to establish perpetual neuronal cultures (Ray et al., 1993). The cultured cells could be passaged, freeze thawed, and recultured. This finding may allow the establishment of cultures from different regions of the CNS and the study of the effects of growth factors and other intrinsic and epigenic factors on development and differentiation of mature neurons and glia from precursor/progenitor cells.

The proliferative nature of neuroblasts also may make it possible to transduce reporter as well as functional genes stably into them. Stable gene transfer into cells requires that the cells proliferate in culture to integrate the transgenes into host cell chromosomes, which will then be passed to daughter cells during cell division. In vitro, precursor cells have been transduced transiently to express the $\beta$-galactosidase ( $\beta$-gal) gene (LacZ) (Price et al., 1987; Cattaneo and McKay, 1990; Williams et al., 1991). In situ lineage mapping studies have used gene transfer by re- troviral vector systems to mark cells in developing CNS. This technique has identified multipotential precursor cells and cells already committed to neuronal or glial fate in the developing cerebral cortex (Price et al., 1987; Luskin et al., 1988, 1993; Price and Thurlow, 1988) and spinal cord (Leber et al., 1990). However, the results from these studies may be less than definitive (Luskin et al., 1993). If the cells can be marked with a marker gene in vitro and then implanted into CNS, the fate of individual cells can be followed more easily. To make neurons more amenable to gene transfer, immortalized neuronal cell lines have been generated by transduction of oncogenes into progenitor cells (Cepko 1988, 1989; Lendahl and McKay, 1990). While these cells can stably express transgenes, they may not retain important properties of primary neurons as oncogenes can cause chromosomal alterations. Stable gene transfer to primary neuronal cells will overcome the problems associated with the use of immortalized cells and allow one to follow the fate of already marked cells in vivo.

In the present study we report that $\mathrm{bFGF}$, at concentrations of $10-100 \mathrm{ng} / \mathrm{ml}$, is a mitogen for neuroblasts. By our definition, neuroblasts are cells that are already committed to neuronal pathways, express neuronal phenotypes, and can retain the capacity to divide. Basic FGF preferentially affects the proliferation of these cells and can maintain these cells in a proliferative state for a long period of time. Basic FGF showed a low level of mitogenic effects on astrocytes in long-term cultures. We present morphological and biochemical characterizations of neuroblast populations that survived and proliferated in response to bFGF and hence were present in the cultures. Our cultures contain a small number of motoneurons, as judged by their immunostaining with ChAT, low-affinity NGF receptor (LNGFR) antibodies, and large size. Further, we can identify cells immunoreactive for glutamic acid decarboxylase (GAD 67) and GABA. Using the proliferative property of bFGF, we have established long-term cultures of neuroblasts that can be maintained as a cell line, passaged by trypsinization, freeze thawed, and recultured. We also report that foreign genes can be stably transduced into neuroblasts by retrovirus-mediated gene transfer. The transfected cells can be passaged, freeze thawed, and cultured again without the loss of the transgene.

\section{Materials and Methods}

\section{Materials}

Medium (DMEM:F12), glutamine (200 mM), and ATV trypsin were from Irvine Scientific (Santa Ana, CA); N2 supplement and laminin were from GIBCO/Bethesda Research Labs (Bethesda, MD). Basic FGF was a gift from Syntex/Synergen Consortium (Boulder, CO). Lab-tek chamber slides (glass) were from Nunc (Naperville, IL). Cell proliferation kits containing bromodeoxyuridine (BrdU), antibody against $\mathrm{BrdU}$, and ${ }^{3} \mathbf{H}$-thymidine were obtained from Amersham (Arlington Heights, IL). Antibodies were from the following sources and used at the indicated dilutions: rabbit anti-NF (200 kDa) antibody (1:500; Chemicon International, Temecula, CA); rabbit anti-NSF (1:800; Polysciences, Warrington, PA); rabbit anti-ChAT (1:5000; a gift from Dr. D. Armstrong, FIDIA, Georgetown Institute of Neuroscience, Washington, DC); rabbit anti-GFAP (1:500; Chemicon International, Temecula, C $\Lambda$ ); rabbit anti-GABA (1:10,000; Sigma, St Louis, MO); rabbit anti-GAD 67 antibody (1:3000; a gift from Dr. A. Tobin, University of California, Los Angeles); monoclonal anti-NSE antibody (1:50; DAKO, Carpenteria, CA); monoclonal anti-NGF receptor (p75) antibody (1:100; a gift from Dr. L. Hersh, University of Kentucky); monoclonal anti-GFAP antibody (1:1000; ICN, Irvine, CA); and monoclonal anti- $\beta$-galactosidase antibody (1:3000; Promega, Madison, WI). Donkey anti-rabbit or anti-mouse antibodies coupled to fluorescein isothiocyanate (FITC), Texas red, or Cy5 were obtained from Jackson ImmunoResearch Laboratories, West Grove, PA. Biotinylated goat anti-rabbit IgG and horse 
anti-mouse IgG were obtained from Vector Laboratories, Burlingame, CA.

\section{Cell culture}

The spinal cords of E14-E16 Fisher rats were dissected. Cords were washed three times with Dulbecco's phosphate-buffered saline (D-PBS) and the supernatant was removed after centrifugation at $1000 \times \mathrm{g}$. Cords were suspended in $5 \mathrm{ml}$ of papain-protease-DNase (PPD) solution and incubated in a $37^{\circ} \mathrm{C}$ water bath for $15 \mathrm{~min}$ with occasional shaking to resuspend the spinal cord fragments. PPD solution was made in Hank's balanced salt solution supplemented with $12.4 \mathrm{mM} \mathrm{MgSO}_{4}$ containing $0.01 \%$ papain, $0.1 \%$ neutral protease, and $0.01 \%$ DNase I (Landon and Robbins, 1986). An equal volume of Dulbecco's minimum essential medium (DMEM) containing 10\% fetal bovine serum and $2 \mathrm{~mm}$ glutamine (complete medium) was added and tissues were dissociated by repeated trituration with medium to fine-bore fire-polished pasteur pipettes. For preplating, cells were centrifuged at $1000 \times g$ for $3 \mathrm{~min}$, resuspended in $1 \mathrm{ml}$ of complete medium, and then plated in a $10 \mathrm{~cm}$ petri dish with $9 \mathrm{ml}$ of complete medium. Cells were incubated at $37^{\circ} \mathrm{C}$ in a $5 \% \mathrm{CO}_{2}$ incubator for 2-3 hr or until most of the non-neuronal cells attached. This preplating step enriched the neuronal cell population in the culture.

The unattached cells were collected, centrifuged at $1000 \times g$ for 3 min, resuspended in $1 \mathrm{ml}$ of N2 medium (DMEM:F12 high-glucose medium containing $5 \mu \mathrm{g} / \mathrm{ml}$ insulin, $50 \mu \mathrm{g} / \mathrm{ml}$ human transferrin, 20 nM progesterone, $100 \mu \mathrm{M}$ putrescine, $30 \mathrm{~nm}$ Na selenite, $2.5 \mathrm{~mm}$ glutamine) containing $20 \mathrm{ng} / \mathrm{ml} \mathrm{bFGF}$, and triturated with a fine-bore Pasteur pipette to make an even suspension. Cell numbers were counted in a hemocytometer and plated at $1 \times 10^{6}$ cells/T75 flask coated with polyornithine (PORN) $(10 \mu \mathrm{g} / \mathrm{ml}) /$ laminin $(5 \mu \mathrm{g} / \mathrm{ml})$. The flasks were coated with PORN $\left(10 \mu \mathrm{g} / \mathrm{ml} \mathrm{H}_{2} \mathrm{O}\right)$ overnight at room temperature, washed twice with water, and then coated with laminin $(5 \mu \mathrm{g} / \mathrm{ml}$ PBS) overnight at $37^{\circ} \mathrm{C}$. Plates were washed twice with PBS and stored in PBS at $-20^{\circ} \mathrm{C}$ until use. Cells were incubated at $37^{\circ} \mathrm{C}$ in a $5 \% \mathrm{CO}_{2}$ incubator. Cells were fed every $3-4 \mathrm{~d}$ with N2 medium containing 20 $\mathrm{ng} / \mathrm{ml} \mathrm{bFGF}(\mathrm{N} 2+\mathrm{bFGF})$.

Cultures ( $80-90 \%$ confluent) were passaged by trypsinization. Cells detached from plates by trypsin were collected in N2 medium, centrifuged at $1000 \times g$ for 3 min, resuspended in N2 + bFGF, and plated. For long-term storage, cells were frozen in N2 + bFGF and $10 \%$ dimethylsulfoxide. To replate, cells were thawed quickly, added to N2 medium, and centrifuged at $1000 \times g$. Cells were resuspended in N2 + bFGF and plated on PORN/laminin-coated plates as previously described.

\section{Proliferation assay}

\section{Bromodeoxyuridine ( $B r d U$ ) immunocytochemistry}

Cells were plated in four-chamber Lab-Tek slides (glass slides coated with $50 \mu \mathrm{g} / \mathrm{ml}$ PORN and $5 \mu \mathrm{g} / \mathrm{ml}$ laminin) and allowed to grow for 3 d. The medium was replaced with fresh medium containing BrdU (Amersham) and incubated for $24 \mathrm{hr}$ at $37^{\circ} \mathrm{C}$ in a $5 \% \mathrm{CO}_{2}$ incubator. Cells were fixed in $4 \%$ paraformaldehyde for $30 \mathrm{~min}$. To reduce nonspecific binding, cells were preincubated with $10 \%$ donkey serum in Tris-buffered saline (TBS) (pH 7.4). Cells were reacted with a monoclonal antibody to BrdU followed by a secondary antibody coupled to Texas red. To determine if neurons were proliferating in culture, cells were double labeled with a polyclonal antibody against NSE. Donkey anti-rabbit IgG coupled with fluorescein isothiocyanate (FITC) was used as a secondary antibody. Cells were visualized in a Bio-Rad MRC 600 confocal scanning laser microscope. Images collected were transferred to an Apple Macintosh Quadra 700, merged using Adobe PHOTOsHoP 2.01 , and printed out on a GCC film recorder.

\section{${ }^{3} H$-thymidine incorporation}

Dose-response of $b F G F$. Cells (passage 2), after washing twice with N2 medium, were plated in a 24 -well plate at a density of $5 \times 10^{4}$ cells/ well in N2 medium containing increasing concentrations of bFGF. Cells were allowed to grow for $3 \mathrm{~d}$ at $37^{\circ} \mathrm{C}$ in a $5 \% \mathrm{CO}_{2}$ incubator. After this time period the medium was changed again with fresh medium containing varying amounts of bFGF (same concentrations as used before) containing $0.5 \mu \mathrm{Ci}$ of ${ }^{3} \mathrm{H}$-thymidine/ml. Cells were incubated for $24 \mathrm{hr}$, washed twice with PBS, and then solubilized in $0.4 \mathrm{~N} \mathrm{NaOH}$ by incubation at $37^{\circ} \mathrm{C}$ for $30 \mathrm{~min}$. The incorporated radioactivity was counted in a $\beta$-counter. Protein concentrations of samples were determined using Coomassie protein assay method (Pierce Chemicals).

Effects of growth factors. Cells (passage 2) were plated in N2 medium containing $20 \mathrm{ng} / \mathrm{ml}$ of specific growth factors and allowed to grow for $3 \mathrm{~d}$, after which time the medium was replaced with fresh medium containing appropriate growth factors and $0.5 \mu \mathrm{Ci} / \mathrm{ml}{ }^{3} \mathrm{H}$-thymidine. ${ }^{3} \mathrm{H}$-thymidine incorporation assay was done as described before.

\section{Immunocytochemistry}

Cells were passaged to PORN $(50 \mu \mathrm{g} / \mathrm{ml}) /$ laminin $(10 \mu \mathrm{g} / \mathrm{ml})$-coated glass Lab-tek chamber slides and allowed to grow for 5-7 d before fixing with $4 \%$ paraformaldehyde in PBS for $30 \mathrm{~min}$ at room temperature. Cells were washed three times with PBS and then permeabilized with $0.25 \%$ Triton $\mathrm{X}-100$. Nonspecific binding was blocked by incubation with $10 \%$ goat serum for polyclonal antibody or $5 \%$ horse serum for monoclonal antibody. For fluorescence labeling, nonspecific binding was blocked by incubation with 5-10\% donkey serum. Antigen-specific staining was examined by either fluorescence labeling or DAB histochemistry. For fluorescence labeling, cells were incubated at $4^{\circ} \mathrm{C}$ overnight with polyclonal or monoclonal antibodies against neurons or astrocytes in the presence of $5 \%$ donkey serum for monoclonal antibodies or $10 \%$ donkey serum for polyclonal antibodies. After washing with TBS containing $0.25 \%$ Triton $X-100$, cells were reacted with a secondary antibody coupled to FITC for polyclonal antibody and Texas red or Cy 5 for monoclonal antibodies for $1-2 \mathrm{hr}$ at room temperature. Cells were washed three times with PBS before mounting with slow fade (Molecular Bioprobe, Eugene, OR). Cells were visualized with a BioRad confocal microscope. For DAB histochemistry, cells were incubated with poly- or monoclonal antibodies against neurons or astrocytes. Bound immunoglobulins were detected by incubating cells for $1 \mathrm{hr}$ with biotinylated goat anti-rabbit IgG or horse anti-mouse IgG followed by ABC complex (Vector Laboratories, Burlingame, CA). The reaction products were visualized by incubating the cultures with $0.04 \%$ diaminobenzidine $(\mathrm{HCl})_{4}, 0.02 \% \mathrm{H}_{2} \mathrm{O}_{2}$, and $0.06 \% \mathrm{NiCl}_{2}$.

\section{Retroviral-mediated gene transfer into spinal cord cells}

Packaging cell line, MIB4, was generated by transfection of CRIP cells with MFG- $\beta$-gal vector (a gift from Dr. R. Mulligan, Whitehead Institute, Boston, MA). The retroviral vector, $M F G$, contains the gag gene up to 1035 bases to increase the packaging efficiencies. This vector does not contain a selectable marker but transfection efficiency has been reported to be $100 \%$ in hematopoietic cells (Ohashi et al., 1992). Spinal cord cells isolated from E14-E16 embryos were plated on PORN/laminin-coated wells of six-well tissue culture plates in N2 + bFGF medium as described before (see cell culture) and allowed to grow at $37^{\circ} \mathrm{C}$ in a $5 \% \mathrm{CO}_{2}$ incubator overnight. Packaging cells were incubated with DMEM medium containing $5 \%$ bovine calf serum overnight at $37^{\circ} \mathrm{C}$ in a $10 \%$ $\mathrm{CO}_{2}$ incubator. The virus was collected, filtered through a $0.45 \mu \mathrm{M}$ filter, and incubated with spinal cord cells in the presence of $4 \mu \mathrm{g} / \mathrm{ml}$ polybrene and $20 \mathrm{ng} / \mathrm{ml} \mathrm{bFGF}$ at $37^{\circ} \mathrm{C}$ in a $5 \% \mathrm{CO}_{2}$ incubator overnight. Next day the medium was changed with $\mathrm{N} 2+$ bFGF medium and incubated further until the wells were $70-80 \%$ confluent. Cells were passaged and maintained as described before.

\section{$\beta$-Galactosidase histochemistry}

Cells, control or infected, were passaged to Lab-tek glass chamber slides and allowed to grow until they were $50-60 \%$ confluent. Cells were fixed with $1.5 \%$ glutaraldehyde for $30 \mathrm{~min}$ at room temperature. After washing with PBS, cells were reacted with a mixture containing $5 \mathrm{~mm} \mathrm{~K}$-ferrocyanide, $5 \mathrm{~mm}$ K-ferricyanide, $2 \mathrm{mM} \mathrm{MgCl}_{2}$, and $40 \mu \mathrm{g} / \mathrm{ml} \mathrm{X-gal} \mathrm{(5^{ \prime } -}$ $3^{\prime}$, West (hester, PA) at $37^{\circ} \mathrm{C}$ overnight. Cells were washed three times in PBS and dehydrated through an ethanol gradient before mounting.

\section{Results}

Morphological characteristics of cells cultured in the presence of $b F G F$

Preplating of spinal cord cells in serum-containing medium removed many non-neuronal cells while most neuronal cells remained unattached (Deloulme et al., 1991). When plated on PORN/laminin-coated dishes in N2 medium (Bottenstein and Sato, 1980) containing bFGF, these unattached cells adhered to 

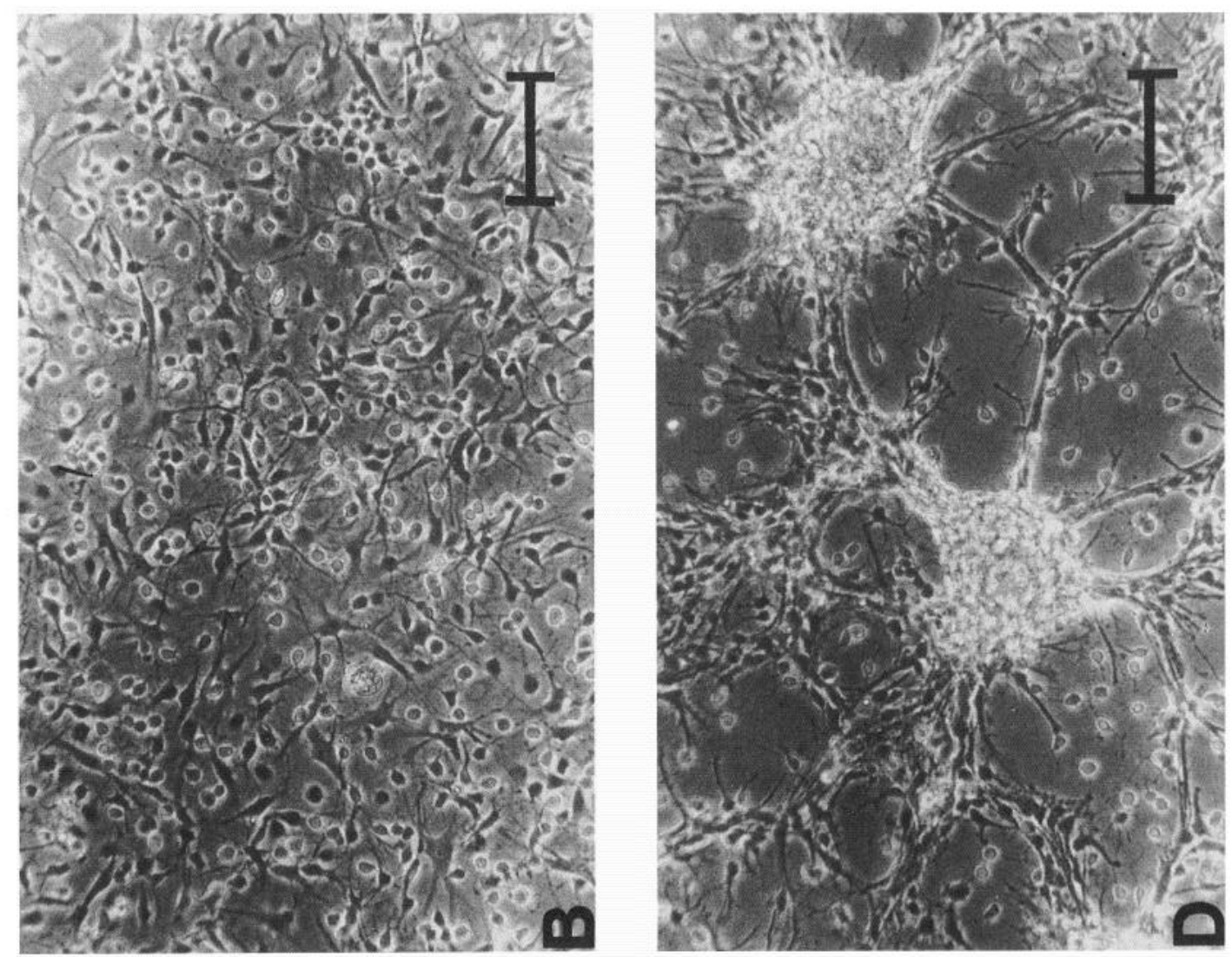

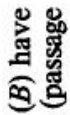

욤

농

式

플

है \&

号豆

ॠ

므대

ष등

के

岁

온.

크용

해의

흐ㅇㅝㅠ

뭉

政

言要

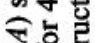

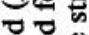

닐
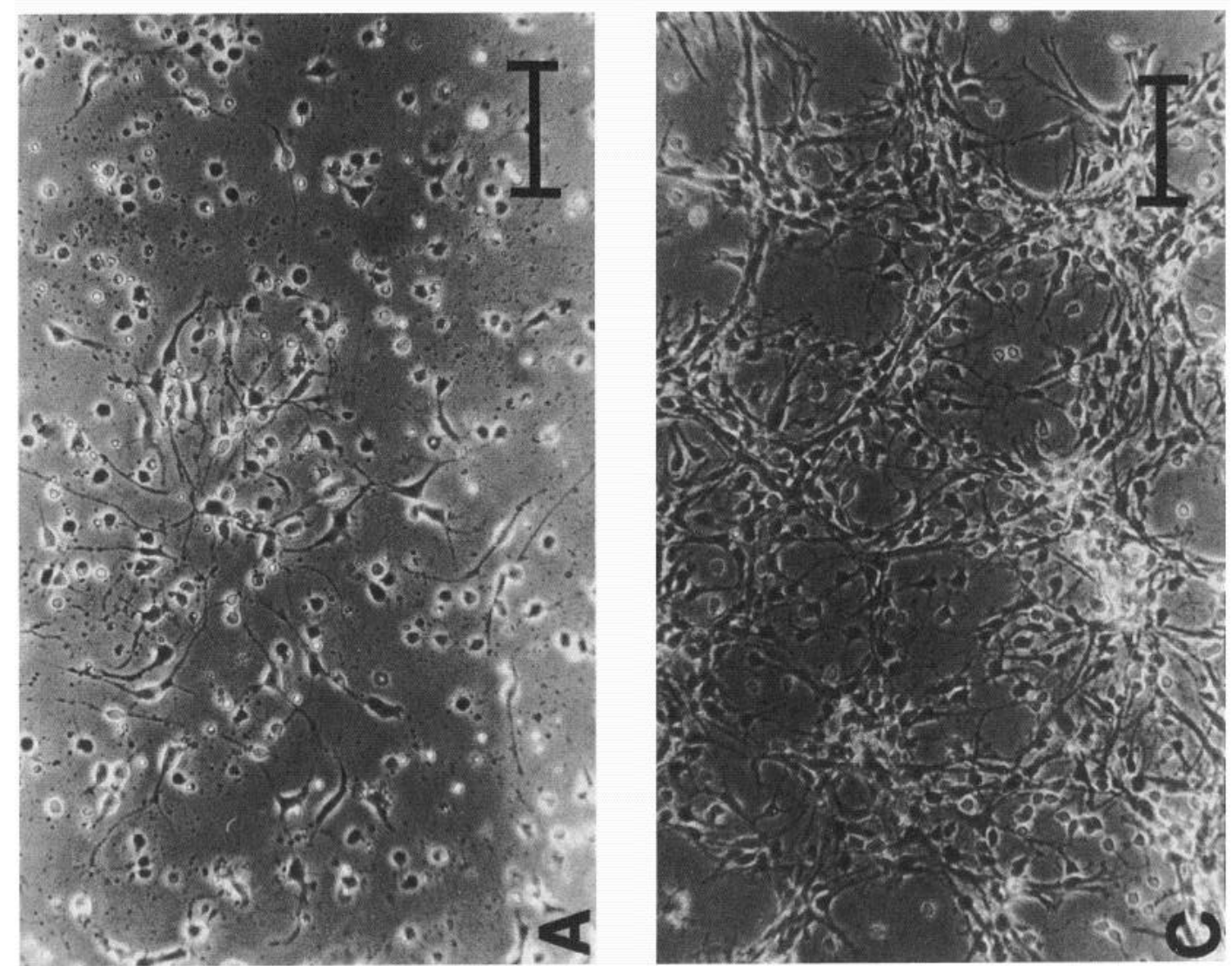

을.

응

工

용

实

要要

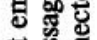

善器

四卷

돈

몬

劳

․ㅗㅀ

8

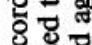

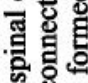

क्षे 8

两安

응협

숭

运密.5

-

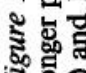




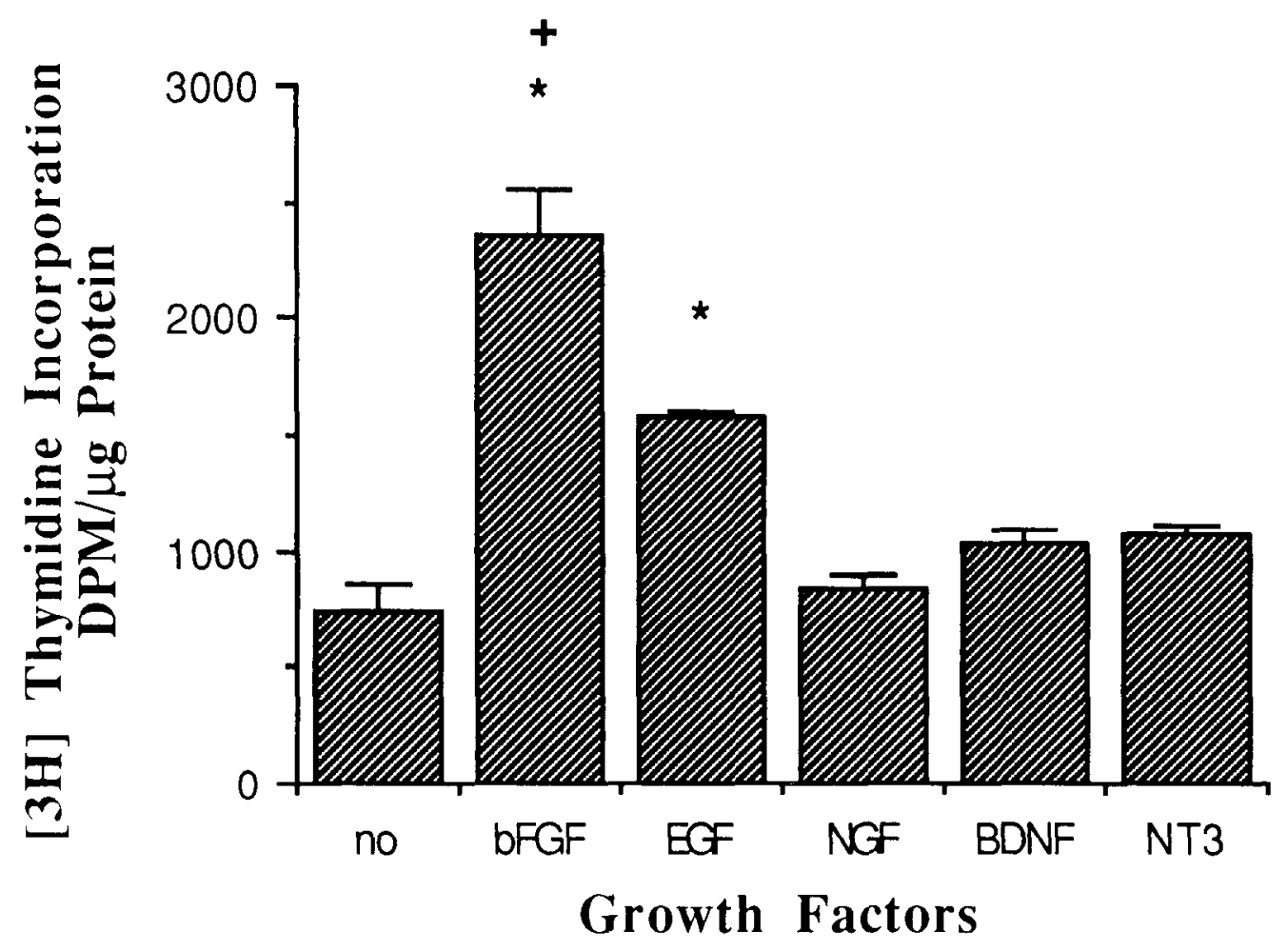

Figure 2. A, Proliferative effects of growth factors on rat spinal cord cells. Cells (grown in bFGF until passage 2) grown in the absence or in the presence of $20 \mathrm{ng} / \mathrm{ml}$ of different growth factors for $3 \mathrm{~d}$ were incubated with ${ }^{3} \mathrm{H}$-thymidine and the growth factors for 24 hr. Values represent mean incorporation of three cultures and are expressed as mean $\mathrm{dpm} / \mu \mathrm{g}$ protein $\pm \mathrm{SEM}$. * represents values different from control (no growth factor) by one-way ANOVA ( $p$ $<0.0001)$ and Fisher post hoc test $(p$ $<0.05) ;+$ represents values different from EGF $(p<0.05)$. B, Dose-dependent survival and proliferative effects of bFGF on spinal cord cells. Cells (passage 2 and cultured in bFGF until passage) were cultured in the presence of indicated amounts of $\mathrm{bFGF}$ for $3 \mathrm{~d}$ and then treated with indicated amounts of bFGF and ${ }^{3} \mathrm{I}$-thymidinc for $24 \mathrm{hr}$. Values represent mean incorporation of three cultures and are expressed as mean $\mathrm{dpm} / \mu \mathrm{g}$ protein $\pm \mathrm{SEM}$. ${ }^{*}$ represents values different from control (no bFGF) by one-way ANOVA $(p<0.004)$ and Fisher post hoc test $(p<0.05)$.
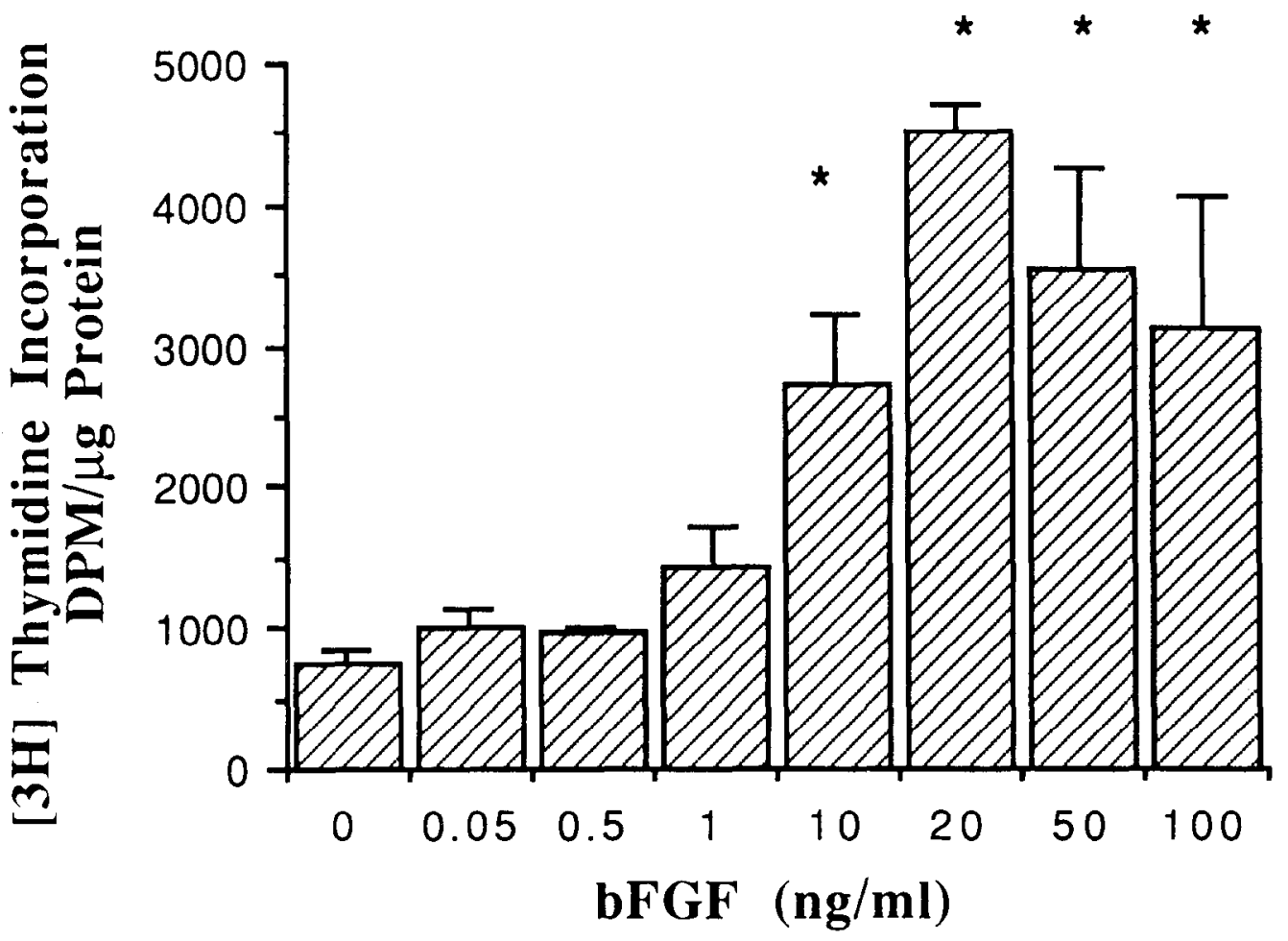

Figure 3. BrdU incorporation, antigenic markers, and transduced gene expression by spinal cord cells. $A$, Cells (passage 1 ) were grown for $3 \mathrm{~d}$ in culture, incubated with BrdU for $24 \mathrm{hr}$, fixed, and then immunostained with antibodies against BrdU (Cy5; red) and NSE (FITC; green). Neurons, as determined by their expression of NSE, had incorporated BrdU. B, A ChAT-positive neuron (FITC; green) had incorporated BrdU (Cy5; red) as determined by double labeling with antibodies against ChAT and BrdU. $C$ and $D, \beta$-Gal gene was stably transduced into spinal cord cells. Passaged cells (passage 4 , postinfection) were immunostained for NSE (FITC; green) and $\beta$-gal (Texas red; red). $C$, One cell in the field expressed both antigens (red/orange), whereas a number of cells in the field expressed only NSE (green), indicating that these cells were not expressing $\beta$-gal. $D$, Cell expressing both $\beta$-gal (Texas red; pink) and NSE (FITC; blue). Note the different cell morphologies of the transfected cells. E, Transfected 

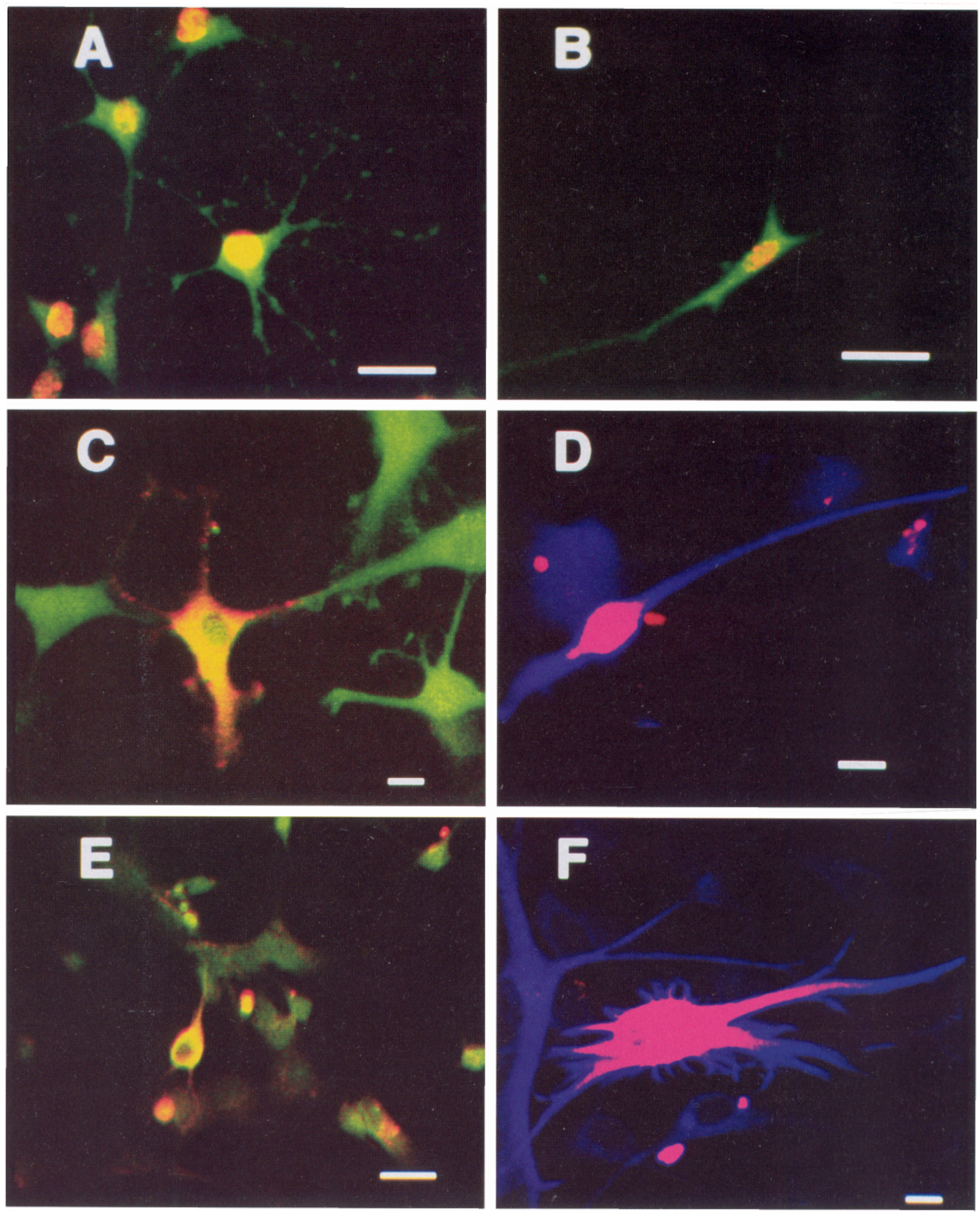

cell (passage 2, postinfection) immunostained for GABA (FITC; green) and $\beta$-gal (Texas red; red). Note that the cell morphology of transfected cells was different from cells shown in $C$ and $D . F$, Some astrocytes in culture (passage 2) stained for both GFAP (FITC; blue) and LNGFR (Texas red; pink), whereas other astrocytes stained for GFAP (blue) but not for LNGFR. Scale bars: $A$ and $B, 20 \mu \mathrm{m} ; C-F, 10 \mu \mathrm{m}$. 

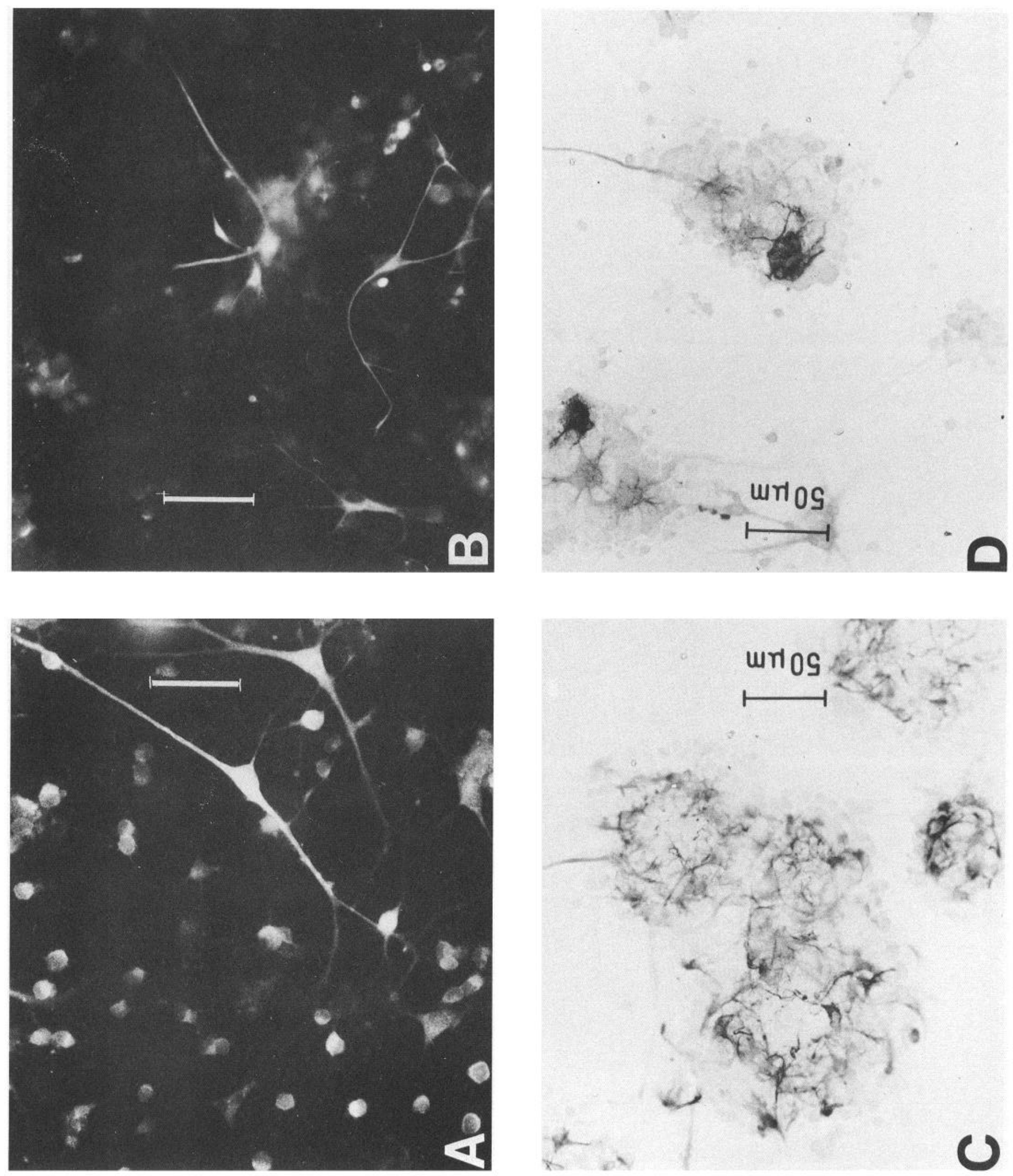
the surface and, within $24 \mathrm{hr}$, formed onc or more small processes. Cells started to proliferate within $2 \mathrm{~d}$ (data not shown) and the newborn cells were small and bipolar in shape (Fig. $1 A$ ). Between 2 and $7 \mathrm{~d}$, both cell bodies and the processes increased in size. The processes started to grow and contacted neighboring cells (Fig. $1 B$; cells in the same culture after $4 \mathrm{~d}$ ). The cell morphology reported here was similar to that reported for spinal cord neurons grown in $\mathrm{N} 2$ medium containing bFGF (Deloulme et al., 1991). Passaged cells (passage 1; Fig. $1 C$ ) had the same morphology and growth patterns as the cells cultured directly from the spinal cord (primary culture). Cells started to form aggregates after this time (around day 6/7) and formed latticelike structures after $15 \mathrm{~d}$ in culture (Fig. $1 D$ ). Although preplating removed most non-neuronal cells from the culture, a few flat, non-neuronal-looking cells were present in these cultures.

\section{Effects of growth factors}

The proliferative effects of a number of growth factors on spinal cord neurons at $20 \mathrm{ng} / \mathrm{ml}$ concentrations have been tested after incubation with ${ }^{3} \mathrm{H}$-thymidine for $24 \mathrm{hr}$ (Fig. $2 A$ ). Basic FGF has the highest proliferative effect (at $20 \mathrm{ng} / \mathrm{ml}$ ), which was significantly different than the effects of other growth factors tested at the same concentration. EGF induced low levels of proliferation; bFGF-treated cells incorporated 1.5 times more ${ }^{3} \mathrm{H}$-thymidine than EGF-treated cells. Other growth factors, NGF, brain-derived neurotrophic factor (BDNF), and NT-3, showed no proliferative effect. The mitogenic effects of bFGF or EGF were the same whether the cells were cultured directly from the brain (primary culture) or maintained in bFGF and passaged several times. This finding suggests that pre-exposure to bFGF had no effect on the proliferation of these cells by other growth factors.

\section{Dose dependence of $b F G F$ effect}

Basic FGF, at concentrations $0.05-1 \mathrm{ng} / \mathrm{ml}$, had survival effects on primary spinal cord cells (data not shown). Similar survival effects of bFGF on primary hippocampal neurons have previously been reported (Ray et al., 1993). Proliferation of spinal cord cells in the presence of increasing concentrations of bFGF was examined by ${ }^{3} \mathrm{H}$-thymidine incorporation assay after $24 \mathrm{hr}$ treatment (Fig. 2B). Cells did not proliferate in low concentrations of bFGF $(0.05-1 \mathrm{ng} / \mathrm{ml})$. However, at $10 \mathrm{ng} / \mathrm{ml}$, cells showed proliferation that increased with increasing concentrations of $\mathrm{bFGF}$, reaching a maximum level at $20 \mathrm{ng} / \mathrm{ml}$. Higher concentrations of bFGF did not increase proliferation. Counting of cells in cultures showed that the proliferation of cells continued with time and, at day $7, \sim 56 \%$ more cells were observed in the presence of $20 \mathrm{ng} / \mathrm{ml} \mathrm{bFGF}$ when compared to day 4 (data not shown). Based on cell counts, the doubling time for spinal cord cells was $2.5 \mathrm{~d}$. The observed proliferative response to bFGF is most likely a combined effect of survival and proliferation, as few cells survived in the absence of bFGF at day 7.

\section{Characterization of proliferating cells}

To determine the nature of cells proliferating in response to $\mathrm{bFGF}$, cells were incubated with BrdU for $24 \mathrm{hr}$, fixed, and then double labeled with antibodies against BrdU and neuron-specific enolase (NSE) protein. These cultures contained a large number $(\sim 70 \%)$ of NSE-positive cells and $\sim 40 \%$ of the NSEpositive cells also had incorporated BrdU. Figure $3 A$ shows NSE-positive cells that have also incorporated BrdU, indicating the neuronal nature of the proliferating cells. Double labeling of cells with antibodies against neurofilament $200 \mathrm{kDa}$ (NF 200) protein and BrdU showed that only a few cells could be immunostained for both antigens (data not shown). Since NF 200 protein is expressed only by differentiated neurons, it is likely that the cultures contain a large population of undifferentiated neurons that divided in response to bFGF treatment but could not be stained for NF 200 protein. To determine the subtypc of neurons proliferating in cultures, cells were immunolabeled with antibodies against BrdU and ChAT. Figure $3 B$ showed a ChAT-positive neuron that has incorporated BrdU.

To determine if astrocytes were proliferating in cultures, BrdUincubated cells were double labeled with antibodies against $\mathrm{BrdU}$ and GFAP (data not shown). The cultures contained $\sim 17 \%$ astrocytes and only $\sim 7 \%$ of GFAP-positive cells incorporated BrdU, indicating that a low number of astrocytes have divided in cultures. Proliferative effects of bFGF on astrocytes have been reported previously (Perraud et al., 1988). Since the number of dividing astrocytes were low in these cultures, we can conclude that the proliferation of cells at passage 2 , as judged by ${ }^{3} \mathrm{H}$ thymidine incorporation, was mostly due to neuroblasts.

\section{Nature of cells in primary and passaged cultures}

The cell populations present in the long-term spinal cord cultures were characterized by immunostaining (Figs. 3, 4). In both primary and passaged cultures, large aggregated and small proliferating cells and their processes were immunostained with antibody against NSE, indicating the neuronal nature of these cells (Figs. 3A, 4A). Anti-NF 200 antibody also stained some cells in cultures (Fig. $4 B$ ). To determine whether astrocytes were proliferating and increasing in number during passages, cells after passage 1 and passage 4 were immunostained with antiGFAP antibody. Total number of cells and number of GFAPpositive cells were counted in the same monolayer culture containing no aggregates. Results showed that the numbers of GFAP-positive cells were $\sim 15 \%$ in passage 1 culture and $\sim 12 \%$ in passage 4 culture, indicating that the number of the astrocytes remained the same with passage. The nature of GFAP-positive cells at two different passages is shown in Figure $4, C$ and $D$.

Immunostaining of the spinal cord cultures for specific neurotransmitters showed that both GABAergic and cholinergic neurons were present (Figs. $3 B, E ; 5 B)$. Only a few cells $(<1 \%)$ in the culture expressed ChAT, GABA, and glutamic acid decarboxylase (GAD 67) (Figs. $3 B, E ; 5 A, B$ ). The number of neu-

Figure 4. Presence of neurons and astrocytes in the spinal cord cultures. Cells grown in culture in N2 + bFGF and passaged were immunostained for different neuronal markers. $A$, cells expressing NSE (passage 6 ); $B$, cells expressing NF 200 protein (passage 2 ). Immunostaining of cells with anti-GFAP antibody showed the presence of astrocytes in the passage 1 cultures $(C)$ and in the passage 4 cultures $(D)$. The number of astrocytes in the cultures remained the same or decreased with passage. Scale bars in $A$ and $B, 50 \mu \mathrm{m}$. 

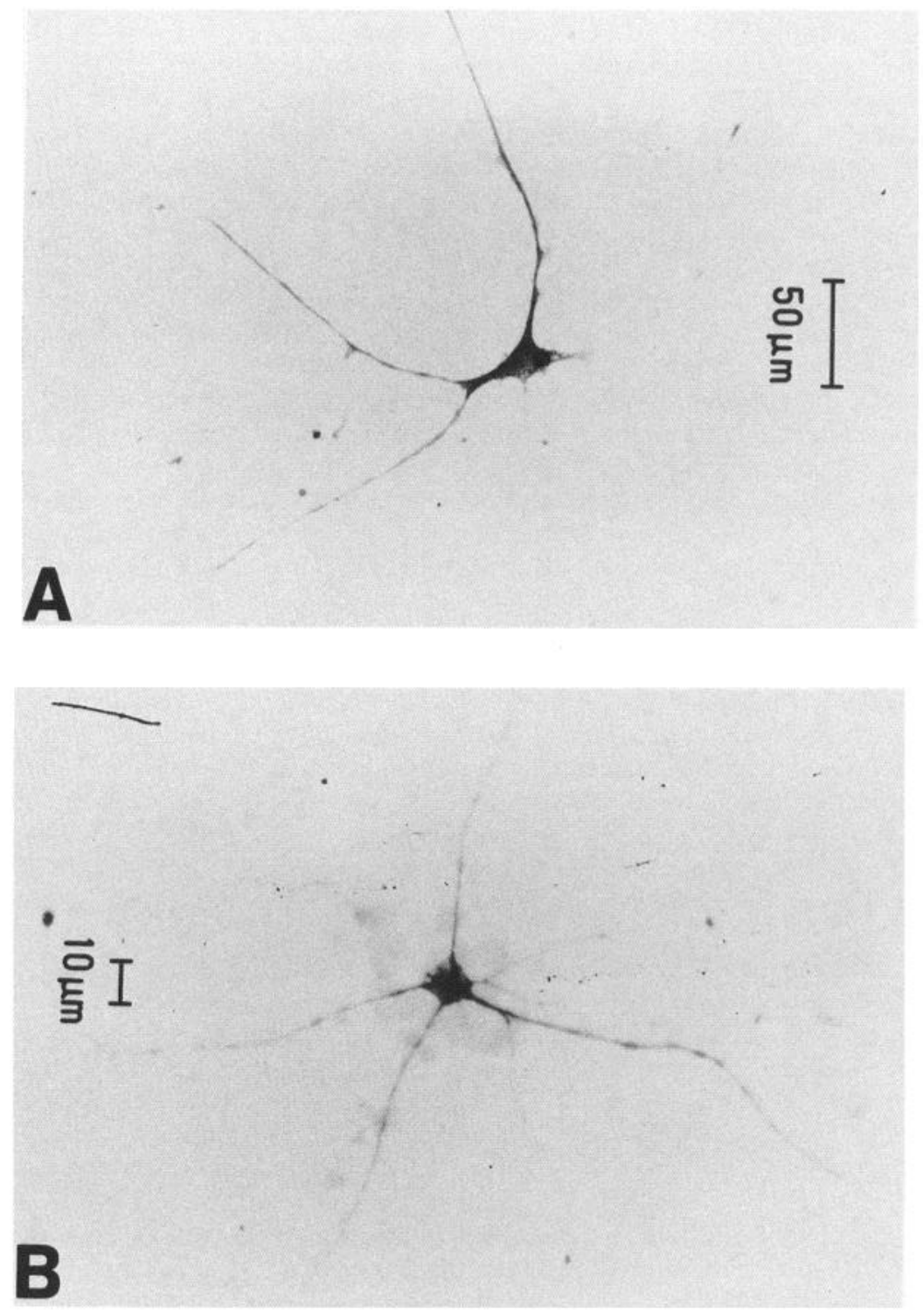

Figure 5. Expression of neurotransmitters and LNGFR by spinal cord neurons. Cells grown in $\mathrm{N} 2+\mathrm{bFGF}$ were passaged and immunostained for neurotransmitters. $A$, ChAT (passage 6); B, GAD 67 (passage 4). Both cell types exhibit a multipolar morphology with several long processes. Cells (passage 4) were immunostained for LNGFR $(C)$. A large number of cells expressed LNGFR in culture. These cells were larger than other cells in the culture.

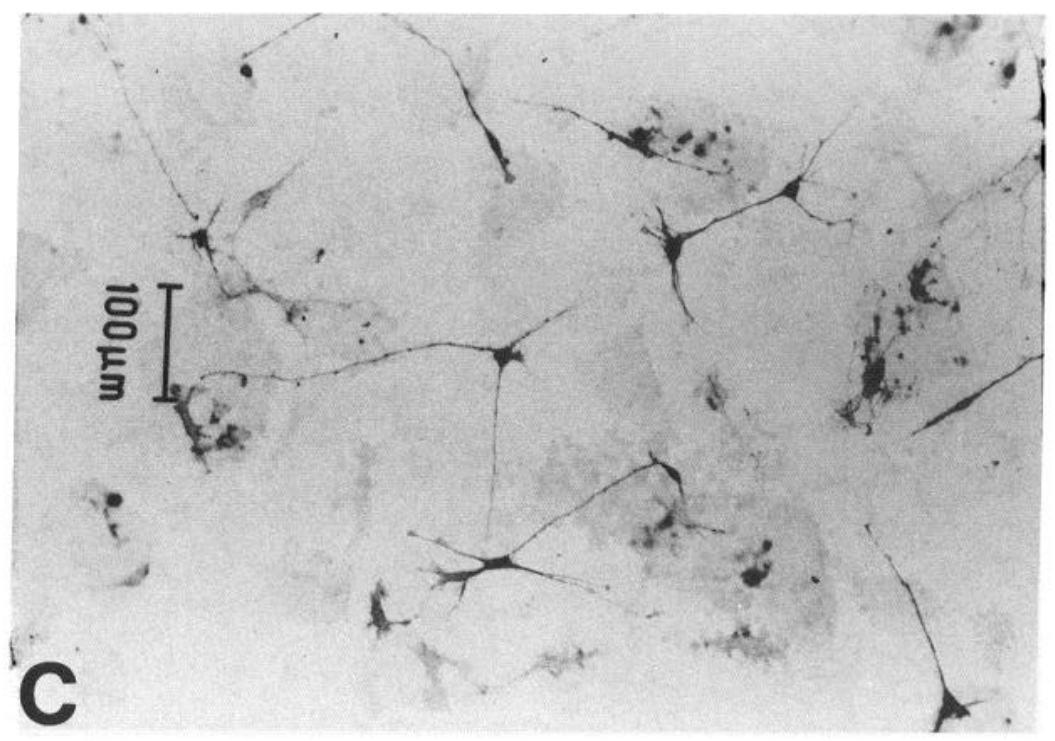


rons staining for GABA and ChAT remained low between the primary and the passaged cultures.

Spinal cord neurons including motoneurons express $75 \mathrm{kDa}$ low-affinity NGF receptor (LNGFR) (Yan and Johnson, 1988; Magal et al., 1991; Chiu et al., 1993). Immunostaining of spinal cord cultures (passage 3 ) showed the presence of a number of LNGFR-positive cells (Fig. 5C). The LNGFR-positive cells in cultures have long processes and the immunostain was localized in both cell bodies and in the processes (Fig. 5C). The sizes of these cells were bigger compared to other cells in culture. Some of the LNGFR-positive cells also expressed ChAT and one example is shown in Figure 6. Expression of both these antigens on the same cells and their large size identified them as motoneurons and these cells were present in passaged cultures (passage 6). However, motoneurons represented only a small population $(<1 \%)$ of cells in these cultures. Some GFAP-positive cells showed LNGFR immunostaining (Fig. $3 F$ ). The morphology of these cells was different from that of the LNGFRpositive cells (Fig. $5 C$ ). However, not all GFAP-positive cells stained for LNGFR (Fig. $3 F$ ), indicating that they represent only a subpopulation.

\section{Gene transfer into primary neurons}

Spinal cord cells were stably transfected with a retroviral vector containing the reporter gene (LacZ) for $\beta$-gal. Histochemical staining of the transfected cells (passage 3 , postinfection) showed that $\sim 12 \%$ of the cells were expressing $\beta$-gal (Fig. $7 A$ ). Untransfected cells showed no staining for $\beta$-gal (Fig. $7 B$ ). To examine whether neuroblasts were transfected by this viral vector and expressing $\beta$-gal, cells (passage 4 , postinfection) were double labeled with antibodies against NSE and $\beta$-gal. A number of cells with different morphologies expressed both $\beta$-gal and NSE (Fig. $3 C, D$ ). Both NSE and $\beta$-gal immunostaining were distributed not only in the cytoplasm but also in the processes. Double labeling of transfected cells with GABA and $\beta$-gal antibodies showed the presence of cells expressing both antigens (Fig. 3E). These results indicated that neuroblasts could be transfected stably to express specific transgenes and could be culturcd and passaged without the loss of transduced genes. Double labeling of cells with antibodies against GFAP and $\beta$-gal detected only few cells expressing both the antigens (data not shown). However, a number of individual cell types expressing $\beta$-gal have not been quantified in these cultures.

\section{Discussion}

\section{Mitogenic effects of $b F G F$ on different cell populations}

Studies related to the development of the rodent cerebral cortex have identified some self-renewable stem cells, multipotential precursor/progenitor cells, and a vast majority of precursor/ progenitor cells that have been committed to either glial or neuronal cell lineages. These stem cells can remain as stem cells or give rise to precursor/progenitor cells that then proliferate into neuroblasts or glioblasts (Fig. 8). The existence of neuroblasts or glioblasts has not been proven, but they have been proposed as intermediate cells that have already been destined to proceed into specific pathways (Stemple and Anderson, 1992; Kilpatrick and Bartlett, 1993; Luskin et al., 1993). Not all precursor/progenitor cells give rise to committed neuroblasts or glioblasts, and some can remain as pluripotent precursor/progenitor cells (Fig. 8).

A recombinant retrovirus containing $\operatorname{Lac} Z$ gene was used to mark a small number of cells whose fate could be studied in vivo (Price et al., 1987; Iuskin et al., 1988, 1993; Price and Thurlow, 1988; Williams et al., 1991). These studies reported that most precursor cells generated either neurons, astrocytes, or oligodendrocytes (Luskin et al., 1988, 1993; Williams et al., 1991), indicating that the glial and neuronal lineages diverge early in development (before E12 for rat). However, a small portion of cells were multipotent and gave rise to both neurons and glia. It is not clear from these studies whether a cell already committed to certain pathways can reverse its commitments and revert back to a previous state in the pathway. For example, can the neuroblasts generated from progenitor/precursor cells remain as neuroblasts under all environmental conditions or can they revert back to progenitor/precursor cells under certain sets of conditions (Fig. 8)? Or once a cell is committed to a defined pathway, is it a terminal commitment? Is this terminal commitment of cells determined by environmental conditions? If the conditions are changed, can the cells revert back to their previous state? The factors that can determine the commitment of cells to certain pathways and maintenance of the cells in the committed states are critical.

A number of growth factors have been implicated in playing a role in the development of the CNS. Among them the mitogenic growth factor $\mathrm{bFGF}$ and its receptors have been reported to be present in the CNS during development and are implicated in regulating the proliferation of undifferentiated precursor cells. This growth factor has proliferative effects on neuronal and glial cells in culture (Gensburger et al., 1987; Perraud et al., 1988; Murphy et al., 1990; Deloulme et al., 1991; Drago et al., 1991). In our cultures, a large portion of NSE-positive cells (>40\%) divide as judged by incorporation of BrdU. Whether cells express NSE while going through the cell cycle (particularly during $S$ phase when they are incorporating BrdU) or express the marker after the cycle has been completed is not possible to ascertain. Similarly, it is not clear whether GFAP expression by astrocytes and BrdU incorporation are simultaneous processes. In addition, although astrocytes were present in our cultures, their proportion remained the same between passages and only a small amount $(-7 \%)$ of thesc cclls proliferated. These results may suggest that neuroblasts preferentially respond to the mitogenic effects of bFGF, which keeps these cells in a continuous proliferative state (Fig. 8). The other mitogenic growth factor, EGF, appears to have proliferative effects on precursor/progenitor cells before they commit to a specific pathway (Reynolds and Weiss, 1992; Reynolds et al., 1992). The precursor/progenitor cells responsive to EGF represent only a small fraction of the total cell populations $(<1 \%)$ and bFGF has no mitogenic effect on these cells (Reynolds and Weiss, 1992; Reynolds et al., 1992). Since exposure to bFGF caused a large number of cells to proliferate in our culture, we were unable to determine whether the small population $(<1 \%)$ of uncommitted precursor/progenitor cells was also proliferating in response to bFGF treatment in our experiments.

\section{Dose dependence effect of $b F G F$}

Basic FGF has previously been reported to have survival effects on neurons isolated from different regions of the brain. Addition of bFGF in highly enriched neuronal cultures lacking detectable glial ceils increased the survival of neurons (Walicke et al., 1986; Hatten et al., 1988; Walicke, 1988; Walicke and Baird, 1988). About $75 \%$ of hippocampal neurons (E16) survived in the presence of $10-30 \mathrm{pg} / \mathrm{ml}$ bFGF for 1 week (Walicke et al., 1986; Walicke and Baird, 1988), and 61\% of cortical neurons (post- 


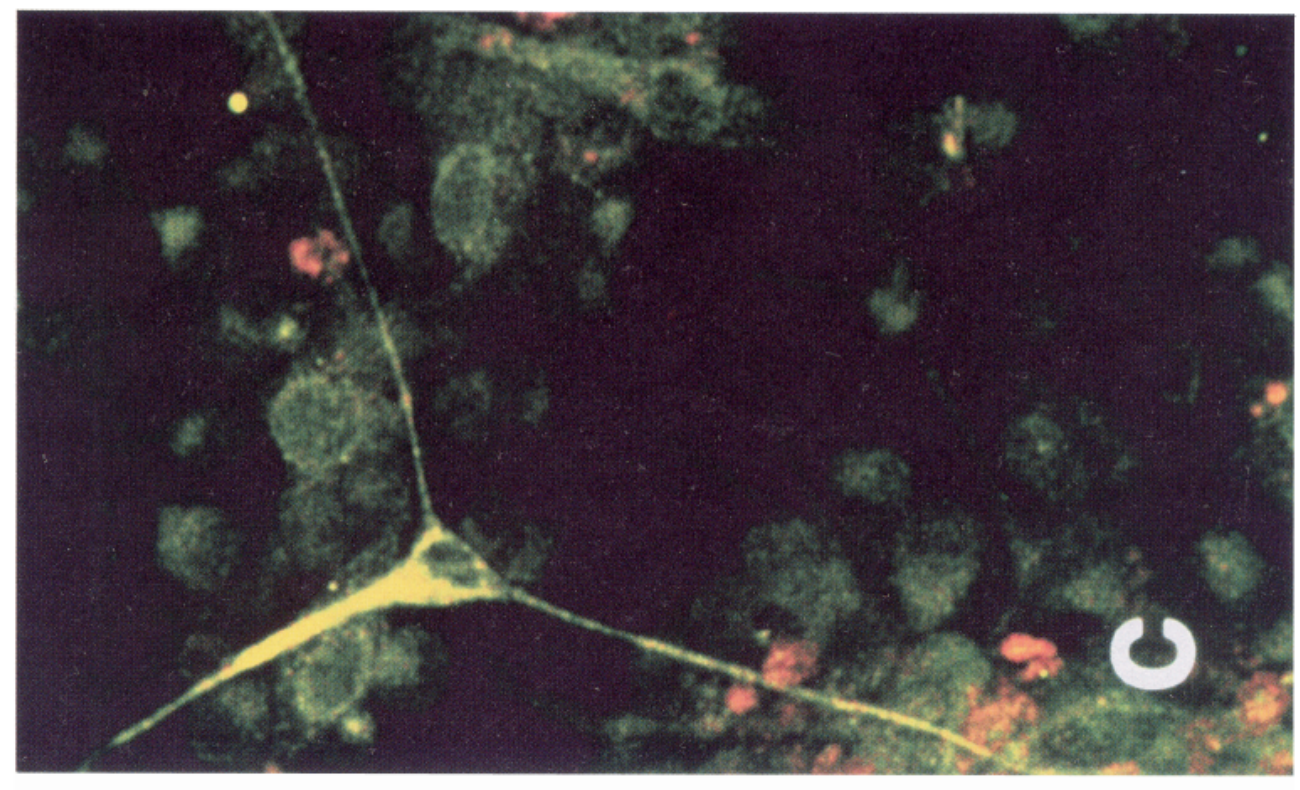

|0.

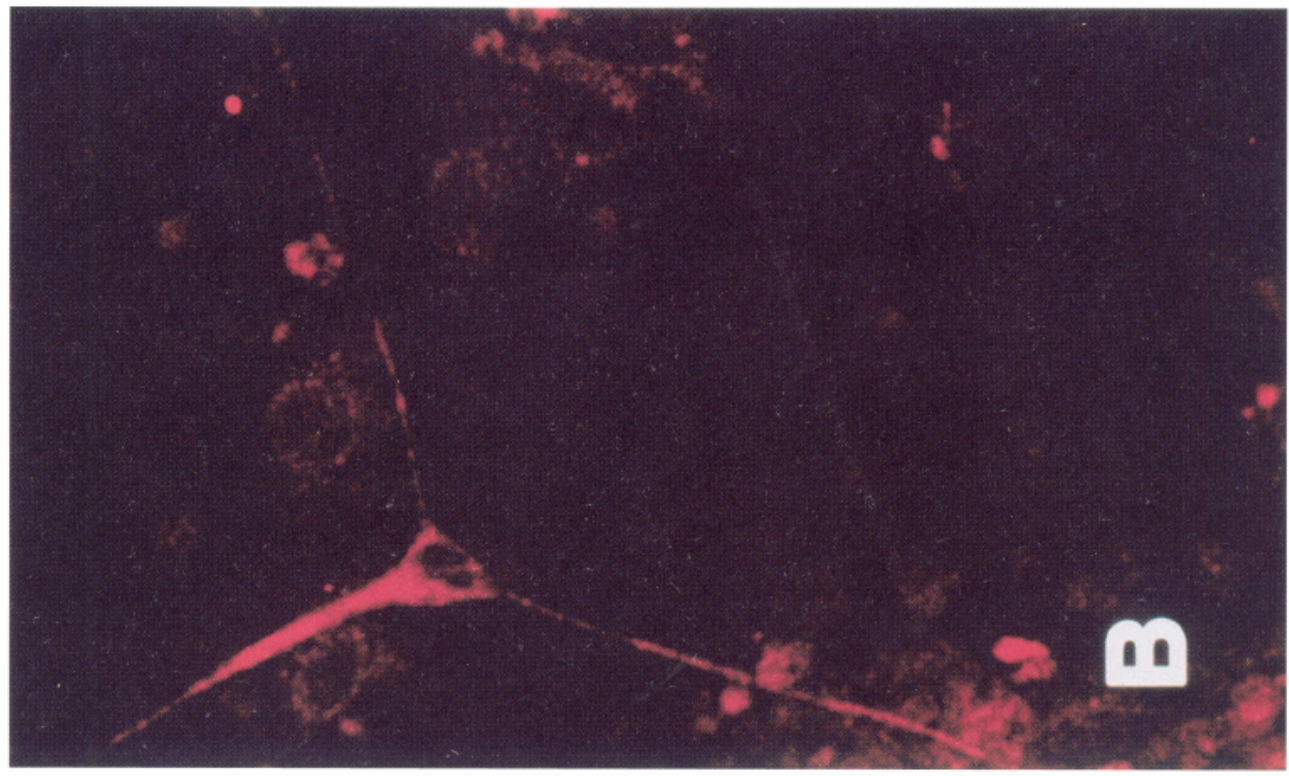

s.

o

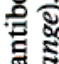

ฮ

落

릉

遍

ज

늠

웡

뭉

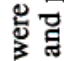

6

远

吅.

卷

홍

उ。

过

혹

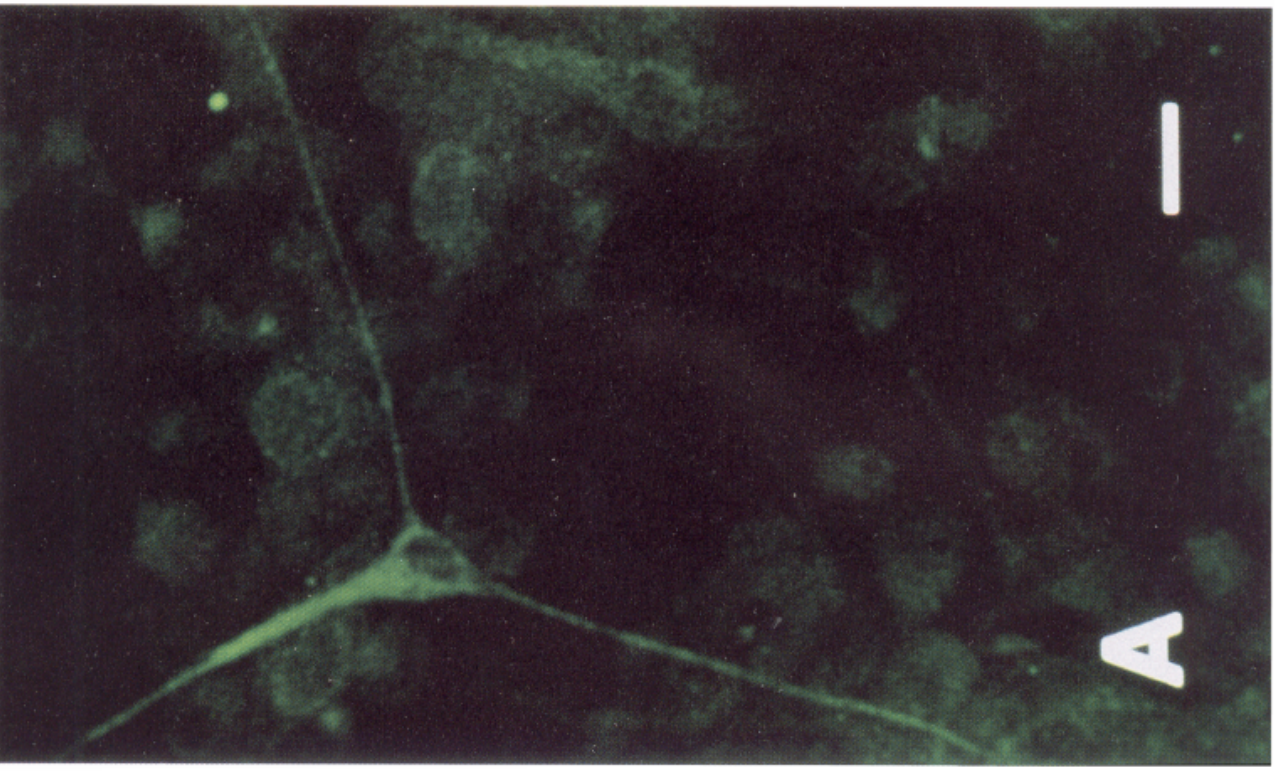

몬

卷羊

ㄹ

类

용

ज्ञात

음

잠.

嵌

흥

5

ट्ष है

पै

웅

总 嵒

齐卷

․ㅛㄹ

之

हैं 

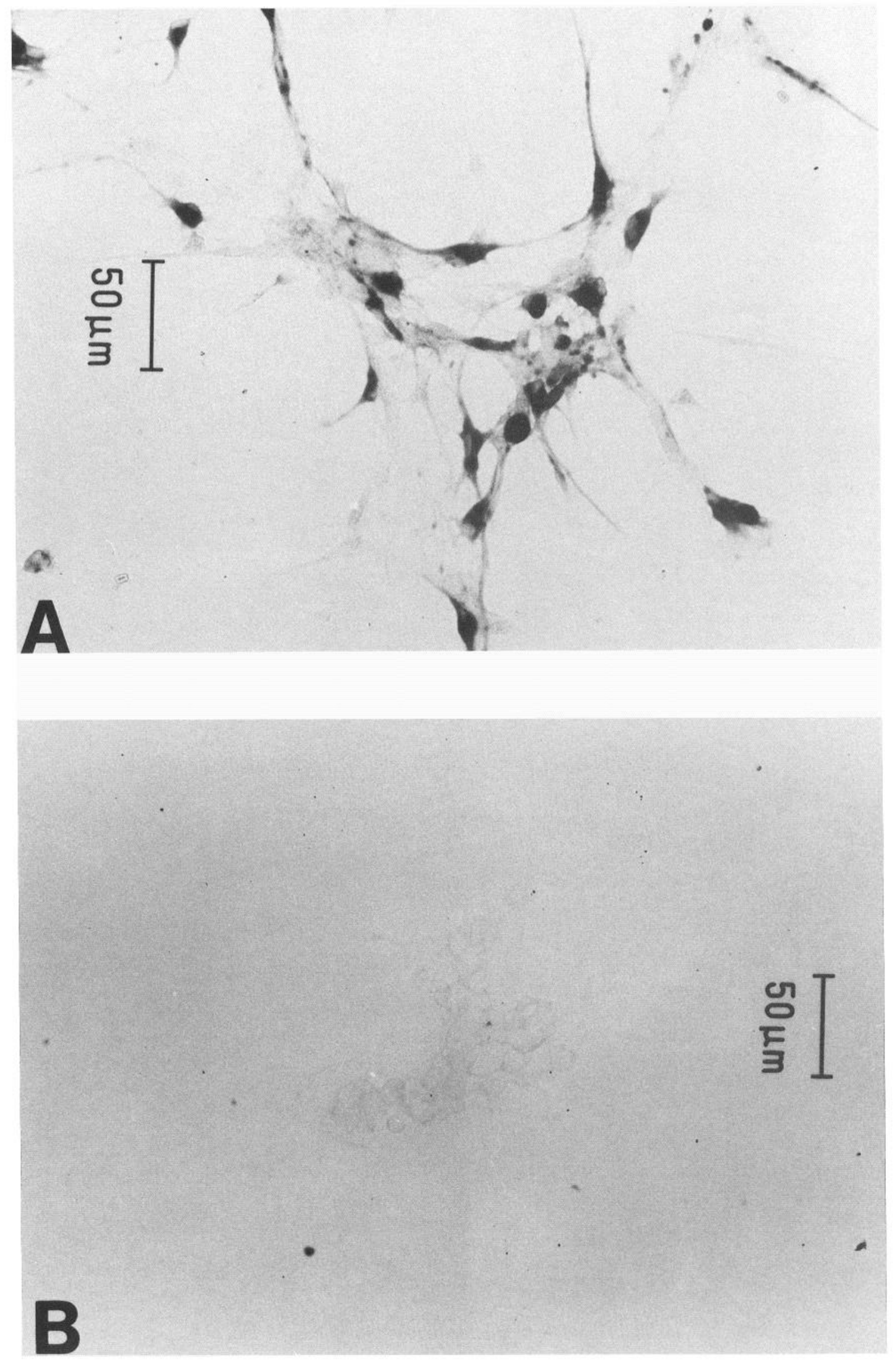

Figure 7. Expression of transduced $\beta$-gal gene by spinal cord cells (passage 3). After $1 \mathrm{~d}$ in culture primary cells were infected with a retroviral virus containing $\beta$-gal gene. Transfected cells were cultured in N $2+$ bFGF and passaged. Cells (passage 3 , postinfection) were fixed and then reacted with X-gal. $A$, cells expressing $\beta$-gal; $B$, untransfected (control) cells did not show any staining. 


\section{NEURAL CELL LINEAGE}

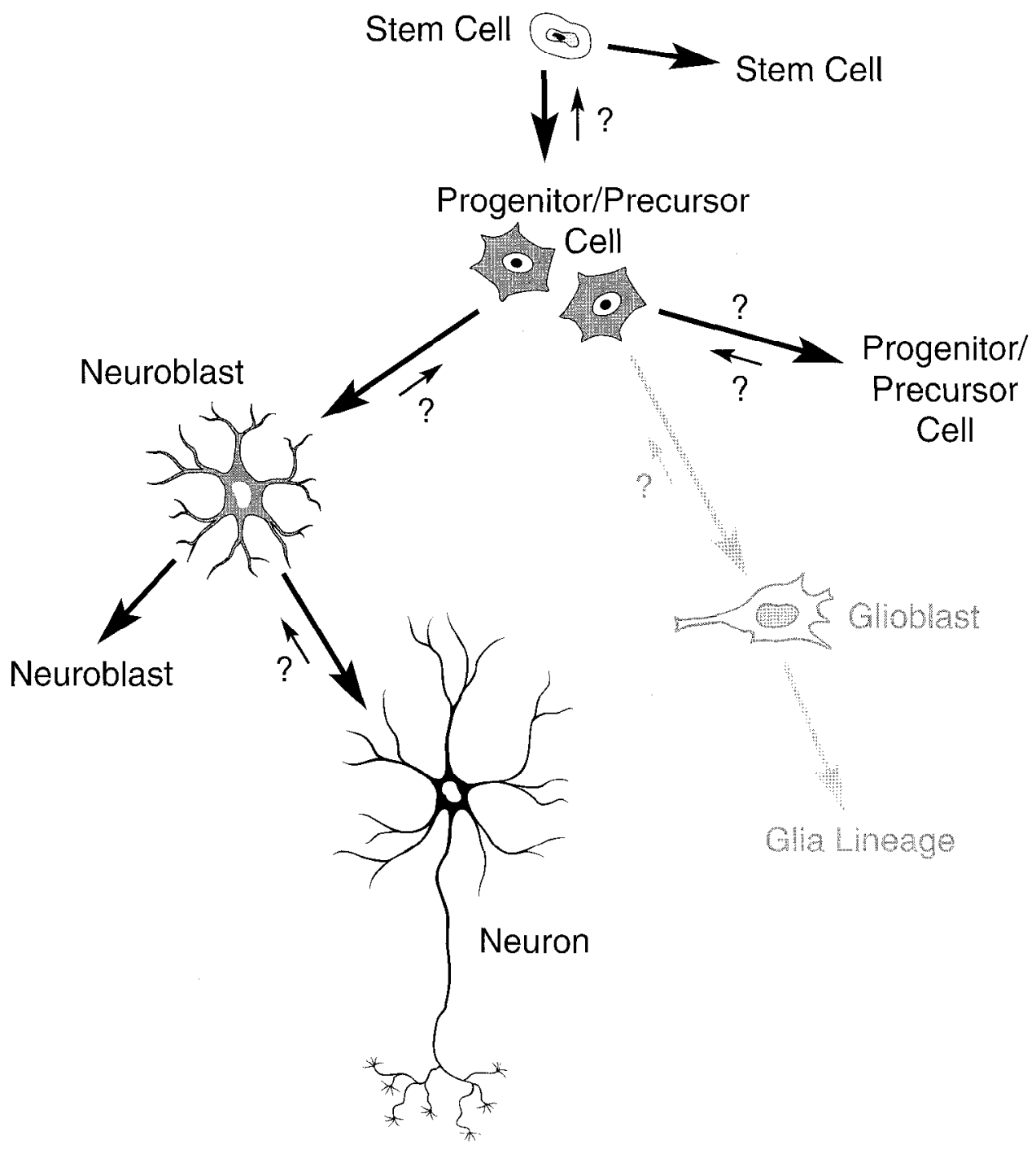

Figure 8. Schematic for generation of neuronal cells from stem cells. A stem cell can remain as a stem cell or can give rise to precursor/progenitor cells. Precursor/progenitor cells may have limited cell renewal and a small portion of these cells can remain as the same cell type. Precursor/progenitor cells in turn give rise to neuroblasts (cells already committed to become neurons and expressing neuronal phenotypes) or gliublasts (shown as shaded) that give rise to type 1 or type 2 progenitor cells (pathways not shown). Neuroblasts under appropriate environmental conditions can differentiate to mature neurons, although a portion of neuroblasts can remain as neuroblasts and proliferate in culture. Basic FGF has proliferative effects on these neuroblasts and maintains them as neuroblasts in culture. Whether any of these committed cells at any stage of development can revert back to their previous state in the pathway (indicated by reverse arrow) is unclear. natal days P0-P1) survived for $11 \mathrm{~d}$ in the presence of $1 \mathrm{ng} / \mathrm{ml}$ bFGF (Morrison et al., 1986). However, bFGF at $1-10 \mathrm{ng} / \mathrm{ml}$ exerted no survival or neurite elongation effects on cerebellar neurons (P0-P1) (Morrison et al., 1988). This difference in survival effects of $b F G F$ on different populations of neurons may be related to the expression of bFGF receptors (FGFR) (Morrison ct al., 1988) and cercbellar neurons at this stage of development may not express the necessary receptors. Our finding of the survival effects of bFGF on spinal cord neuroblasts at low concentrations was similar to the dose dependence effects of bFGF on the hippocampal neurons in vitro (Ray et al., 1993). Like hippocampal cells, bFGF at higher concentrations had proliferative effects on spinal cord cells, $20 \mathrm{ng} / \mathrm{ml}$ being the optimum concentration (Fig. $2 B$ ). Similar mitogenic effects of bFGF on these two distinct populations, which are not clearly related, may suggest that the mitogenic effect of bFGF is not restricted to a class of phenotypically distinct neuronal cells but that bFGF has a proliferative effect on a number of different neuroblast populations irrespective of the regions from which they were isolated.
Similar dose-dependent effects of bFGF on both hippocampal and spinal cord cells suggest that the same bFGF receptors (FGFR) may be involved in these processes in both cell types. The survival and proliferative responses to bFGF may be caused by efficacy of stimulation of the same receptor, or by the involvement of different bFGF receptors. Basic FGF binds to two major types of binding sites: low-affinity heparan sulfate proteoglycans (HSPGs) and high-affinity receptor proteins. Binding to both receptors is necessary for the neurotrophic activity (Klagsbrun and Baird, 1991). So far, four different high-affinity receptors ( $f l g$, bek, FGFR-3, FGFR-4) for FGF have been described (Kornbluth et al., 1988; Lee et al., 1989; Dionne et al., 1990; Keegan et al., 1991; Partanen et al., 1991). Expression of mRNA of $f l g$ has been localized by in situ hybridization in the developing and adult spinal cord of rats (Wanaka et al., 1990, 1991). The expression of HSPGs (low affinity) and a high-affinity membrane receptor protein $(f l g)$ has been detected in cultured hippocampal neurons (Walicke et al., 1989). However, expression of other high-affinity receptors in developing or adult spinal cord or in cultured neurons has not been examined. In the 
present study, cultured spinal cord neuroblasts showed a differential responsiveness when treated with low or high concentrations of bFGF (Fig. 2B). Based on this observation, it will be important to examine the expression and modulation of different FGFR molecules in response to low and high doses of bFGF to determine the mechanism of the survival versus proliferative effects of this growth factor.

\section{Proliferative effects of other growth factors}

Of all the other growth factors tested in this study, only EGF exerted proliferative effects qualitatively similar to the effect of bFGF, although to a lesser extent. The mitogenic polypeptide, EGF, had survival effects on cells from neonatal (P1 rat) subneocortical telencephalon and cerebellum in vitro (Morrison et al., 1987, 1988). In vitro, EGF had proliferative effects on progenitor cells of embryonic striatum presumably of the subependymal layer (Reynolds et al., 1992). In the continued presence of EGF in serum-free cultures, a colony of proliferating cells generated from a single progenitor cell showed the presence of both neurons and glia, the latter being the dominant cell type.

In our study, although EGF at the same concentration as bFGF showed proliferative effects on spinal cord cells, the effect was higher in bFGF-treated cultures than in EGF-treated cultures. The observed smaller effect of EGF may be because (1) the dose of EGF is not optimum and a lower or higher dose of EGF may have larger proliferative effects on these cell populations, (2) EGF is not as efficacious as bFGF, (3) only a small subpopulation of cells $(<1 \%)$ as described by Reynolds et al. (1992) divided in response to EGF treatment, or (4) the population sensitive to EGF is not the same population sensitive to bFGF. However, Kornblum et al. (1990) have reported that bFGF and EGF affect an overlapping population of cells in cortical cultures. Since a lower number of cells proliferated in response to EGF compared to bFGF, perhaps only a subpopulation of bFGF-responsive cells also proliferate in the presence of EGF. Examination of the proliferation of spinal cord cells by EGF at different doses of EGF may answer some of the questions raised here.

We report that NGF, BDNF, or NT-3 had undetectable proliferative cffects on culturcd spinal cord neurons at $20 \mathrm{ng} / \mathrm{ml}$ concentration (Fig. $2 A$ ). However, we cannot rule out the possibility that another concentration of growth factors different than that used in the present study and/or other combinations of factors may show proliferative effects on spinal cord neurons. Besides, we have examined only the proliferative effects of these growth factors and they may have survival or differentiation effects on spinal cord neurons. It is pussible that the cells that fail to respond to a specific neurotrophic factor may not express the specific trk receptor (Cordon-Cardo et al., 1991; Kaplan et al., 1991; Klein et al., 1991) necessary for the action, or that the in vitro environment was not conducive for receptor-ligand binding. Various interactions between growth factors appear to occur through reciprocal regulation of their receptors. For example, the additive effects of growth factors on neuronal proliferation have been previously reported (Cattaneo and McKay, $1990)$.

\section{Generation of neuronal cells during embryogenesis}

Studies of the generation of neurons within the cervical spinal cord of rat have shown that all neurons are produced in a ventrodorsal sequence between embryonic days 11 and 16 (E11 and E16) (Nornes and Das, 1972, 1974; Altman and Bayer, 1984).
Motoneurons are born on E1 1 and E12 in a ventrodorsal gradient with the peak of motoneuron generation at E13 (Nornes and Das, 1972, 1974; Altman and Bayer, 1984; Phelps et al., 1988). ChAT-positive cells are born between E1 1 and E1 3 and the cholinergic central canal cluster and dorsal horn cells are born on E13-E14 (Phelps et al., 1988). Studies on numerical loss of motoneurons during development showed that there was a $40-45 \%$ loss of these cells between E1 5 and postnatal days 15 (Oppenheim, 1986). Long-term culturing of cells from E14E16 embryos to study the mitogenic effects of bFGF on neuronal cells has allowed us to include the maximum number of cells, as most cells have been born by this time and the major cell death has not yet started to occur.

\section{Presence of non-neuronal cells in spinal cord cultures}

A number of methods have been described previously for culturing spinal cord neurons from mammals (Smith and Appel, 1983; McManaman et al., 1985; Erkman et al., 1989; Magal et al., 1991). Most of these methods used serum in the cultures that allowed the growth of neuronal as well as non-neuronal cells. Preplating of dissociated CNS cells on plastic tissue culture plates in serum-containing medium allowed non-neuronal cells to attach to the substratum faster than the neurons. Using this preplating technique and culturing cells in serum-free medium (Bottenstein and Sato, 1980), researchers have established shortterm neuronal cultures from rat spinal cord neurons that are about $98 \%$ pure (Digby et al., 1985; Deloulme et al., 1991). We have preplated the spinal cord cells and cultured them in N2 medium on PORN/laminin-coated plates to reduce the presence of non-neuronal cells. Our spinal cord cultures contained $\sim 17 \%$ astrocytes throughout multiple passages. The continued presence of astrocytes in these cultures may be due to the fact that bFGF is supporting their survival and/or a low level of proliferation. Another possibility is that bFGF has proliferative effects on a small population of multipotent precursor/progenitor cells, which differentiate into both neurons and astrocytes.

\section{Characterization of neuronal populations}

A large number of cells $(\sim 70 \%)$ in our cultures stained for the neuronal marker NSE. Staining by NSE of about $98 \%$ of cells in primary spinal cord cultures has been reported (Deloulme et al., 1991). In the present study, passaged cultures showed the presence of some cells staining for NF 200 protein. Since NF 200 is expressed only by differentiated neurons this result may indicate that, at high concentrations of bFGF, most cells in culture were actively dividing and had not fully differentiated. Our spinal cord cultures, which had been passaged several times, contained cholinergic-, GABAergic-, and LNGFR-positive neurons. Previous studies have found a similar diversity of cell populations in primary culture. In spinal cord cultures, the presence of ChAT-positive and LNGFR-negative, ChAT-negative and LNGFR-positive, and ChAT-positive and LNGFR-positive cells has been reported (Magal et al., 1991), with the ChATpositive and LNGHR-positive cells most probably representing the motoneuron populations in the cultures. Our spinal cord cultures, which have becn maintained for 5 months and passaged several times (passage 7), contained individual populations of ChAT-positive and LNGFR-positive cells (Fig. 5). In addition, we have localized both antigens in the same cells (Fig. 6).

We have found that a small number of astrocytes expressed LNGFR (Fig. 3F). Using a quantitative-polymerase chain re- 
action, LNGFR has been detected in astrocytes cultured from rat pups (Hutton et al., 1992). However, LNGFR protein was not detected by immunocytochemistry in cultured astrocytes (Assoulin and Pantazis, 1989). Furthermore, treatment with NGF increased the expression of LNGFR mRNA in astrocytes (Hutton et al., 1992). Our ability to detect LNGFR in astrocytes by immunocytochemistry may be because (1) cells were cultured from E14-E16 embryos and not from pups and (2) bFGF, like NGF, may have increased the expression of LNGFR in astrocytes to a level that can be detected by immunocytochemistry.

\section{Gene transfer}

To demonstrate further that neuroblasts were dividing in cultures in response to bFGF, we attempted to transduce the reporter gene LacZ into these cells. Only rapidly dividing cells can integrate a transgene stably into the chromosome. LacZ could be transduced stably into neuroblasts using retroviral-mediated gene transfer, as evidenced by expression of $\beta$-gal by NSE-positive cells (Fig. $3 C, D$ ). These cells could be maintained in culture for a long period of time ( 4 months and passage 6 ) and passaged without losing the transgene. About $12 \%$ of transfected cells expressed $\beta$-gal. This may indicate that only $12 \%$ of the cells were infected by this vector, or that a higher number of cells wcre infectcd but were not expressing this gene at levels detectable by histochemical staining. A number of cell lineage studies have used retroviral-mediated gene transfer into precursor cells in vitro for transient gene expression (Price et al., 1987; Luskin et al., 1988; Cattaneo and McKay, 1990; Williams et al., 1991). To overcome the difficulties of transducing genes stably into primary neurons, immortalized cell lines have been generated (Cepko, 1988, 1989; Ryder et al., 1989; Lendhal and McKay, 1990) and subsequently used for grafting (Renfranz et al., 1991; Snyder et al., 1992). When grafted into the brains of neonatal rats, these immortalized cells retained the capacity to differentiate into neurons and glia. However, immortalization of cells by oncogenes can cause chromosomal alterations and, as a result, altered developmental properties, so the development and differentiation of the immortalized cells in vitro or in vivo may be different from primary cells. The ability to use a defined population of neuroblasts expressing the transgenes in the grafting paradigm will help investigate the fate of cells in vivo during growth and differentiation.

\section{Conclusion}

This study showed that bFGF has proliferative effects on neuroblasts (cells already committed to become neurons). Neuroblasts differ from stem cells and multipotent precursor/progenitor cells in that neuroblasts already have neuronal phenotypes and preferentially respond to the mitogenic effects of bFGF, which can keep them in a proliferative state for a long period of time in culture. Although astrocytes were present in our cultures and bFGF has been reported to have proliferative effects on these cells, the proportion of astrocytes in these cultures remained the same over time. Using the mitogenic effects of bFGF, long-term cultures of neuroblasts from spinal cord have been established to examine the survival, proliferation, and differentiation effects of bFGF and other growth factors on different neuronal cell populations. Experiments conducted with these long-term cultures will help to answer fundamental questions regarding the dynamics of interactions between cells and their environments, which may influence their fate in specific stages in the cell pathways. The ability to transduce foreign genes stably into ncuroblasts and maintain these cells in culture without the loss of transgene will allow the transplantation of these cells into the spinal cords of rats to study phenotypic behavior of previously marked and, as a result, defined cell populations during growth, development, and differentiation in vivo.

\section{References}

Alderson RF, Alterman AL, Barde Y-A, Lindsay RM (1990) Brainderived neurotrophic factor increases survival and differentiated functions of rat septal cholinergic neurons in culture. Neuron 5:297-306.

Altman J, Bayer SA (1984) The development of rat spinal cord. In: Advances in anatomy, embryology and cell biology, Vol 85 (Beck F, Hild W, van Limborgh I, Ortmann R, Pauly JE, Schiebler TH, eds) pp 1-166. Berlin: Springer.

Arakawa Y, Sendtner M, Thoenen H (1990) Survival effect of ciliary neurotrophic factor (CNTF) on chick embryonic motoneurons in culture: comparison with other neurotrophic factors and cytokines. J Neurosci 10:3507-3515.

Assouline JG, Pantazis NJ (1989) Detection of a nerve growth factor receptor on fetal human schwann cells in culture: absence of the receptor on fetal human astrocytes. Dev Brain Res 45:1-14.

Bottenstein JE, Sato G (1980) Growth of a rat neuroblastoma cell line in serum-free supplemented medium. Proc Natl Acad Sci USA 76: 514-517.

Cattaneo E, McKay RDG (1990) Proliferation and differentiation of neuronal stem cells regulated by nerve growth factor. Nature 347 : $762-765$.

Cepko CL (1988) Immortalization of neuronal cells via oncogene transduction. Trends Neurosci 11:6-8

Cepko CL (1989) Immortalization of neural cells via retrovirus-mediated oncogene transduction. Annu Rev Neurosci 12:47-65.

Chiu AY, Chen EW, Loera S (1993) A motor neuron-specific epitope and the low-affinity nerve growth factor receptor display reciprocal patterns of expression during development, axotomy, and regeneration. J Comp Neurol 328:351-363.

Cordon-Cardo C, Tapley P, Jing S, Nanduri V, O'Rourke E, Lamballe F, Kovary K, Klein R, Jones KR, Reichardt LF, Barbacid M (1991) The $t r k$ tyrosine protein kinase mediates the mitogenic properties of nerve growth factor and neurotrophin-3. Cell 66:173-183.

Deloulme JC, Baudier J, Sensenbrenner M (1991) Establishment of pure neuronal cultures from fetal rat spinal cord and proliferation of the neuronal precursor cells in the presence of fibroblast growth factor. J Neurosci Res 29:499-509.

Digby J, Harrison R, Jehanli A, Lunt GG, Clifford-Rose F (1985) Cultured rat spinal cord neurons: interaction with motor neuron disease immunoglobulins. Muscle Nerve 8:595-605.

Dionne CA, Crumley G, Bcllot F, Kaplow JM, Searfoss G, Ruta M, Burgess WH, Jaye M, Schlessinger J (1990) Cloning and expression of two distinct high-affinity receptors cross-reacting with acidic and basic fibroblast growth factors. EMBO J 9:2685-2692.

Drago J, Murphy M, Carroll SM, Harvey RP, Bartlett PF (1991) Fibroblast growth factor-mediated proliferation of central nervous system precursors depends on endogenous production of insulin-like growth factor I. Proc Natl Acad Sci USA 88:2199-2203.

Erkman L, Touzeau G, Bertrand D, Bader CR, Kato AC (1989) Characterization of dissociated monolayer cultures of human spinal cord. Brain Res Bull 22:57-65.

Gensburger C, I abourdette G, Sensenbrenner M (1987) Brain basic fibroblast growth factor stimulates the proliferation of rat neuronal precursor cells in vitro. FEBS Lett 217:1-5.

Gonzales A-M, Buscaglia M, Ong M, Baird A (1990) Distribution of basic fibroblast growth factor in the 18-day rat fetus: localization in the basement membranes of diverse tissues. J Cell Biol 1 10:753-765.

Hatikka J, Hefti F (1988) Comparison of nerve growth factor's effects on development of septum, striatum, and nucleus basalis cholinergic neurons in vitro. J Neurosci Res 21:352-364.

Hatten ME, Lynch M, Kydel RE, Sanchez J, Joseph-Silverstein J, Moscatelli D, Rifkin DB (1988) In vitro neurite extension by granule neurcns is dependent upon astroglia-derived growth factor. Dev Biol I 25:280-289.

Hughes RA, Sendtner M, Goldfarb M, Lindholm D, Thoenen H (1993) Evidence that fibroblast growth factor 5 is a major muscle-derived survival factor for cultured spinal motoneurons. Neuron 10:369-377.

Hughes SM, Lillien LE, Raff MC, Rohrer H, Sendtner M (1988) Ciliary 
neurotrophic factor induced type-2 astrocyte differentiation in culture. Nature 335:70-73.

Hutton LA, de Vallis J, Perez-Polo JR (1992) Expression of p75 $\operatorname{Trk} A$, and $\operatorname{Tr} k B$ mRNA in rat $\mathrm{C} 6$ glioma and type I astrocyte cultures. J Neurosci Res 32:375-383.

Ip NY, Li Y, Yancopoulos GD, Lindsay RM (1993) Cultured hippocampal neurons show responses to BDNF, NT-3, and NT-4, but not NGF. J Neurosci 13:3394-3405.

Kaplan DR, Hempstead BL, Martin-Zanca D, Chao MV, Parada LF (1991) The $t r k$ proto-oncogene product: a signal transducing receptor for the nerve growth factor. Science 252:554-558.

Kato H, Wanaka A, Tohyama M (1992) Co-localization of basic fibroblast growth factor-like immunoreactivity and its receptor mRNA in the rat spinal cord and the dorsal root ganglion. Brain Res 576: $351-354$.

Keegan K, Johnson DE, Williams LT, Hyman MJ (1991) Isolation of an additional member of the fibroblast growth factor receptor family, FGFR-3. Proc Natl Acad Sci USA 88:1095-1099.

Kilpatrick TJ, Bartlet PF (1993) Cloning and growth of multipotential neuronal precursors: requirements for proliferation and differentiation. Neuron 10:255-265.

Klagsbrun M, Baird A (1991) A dual receptor system is required for basic fibroblast growth factor activity. Cell 67:229-231.

Klein R, Jing S, Nanduri V, O'Rourke E, Barbacid M (1991) The trk proto-oncogene encodes a receptor for nerve growth factor. Cell 66 : 967-979.

Kornblum HI, Raymon HK, Morrison RS, Cavanaugh KP, Bradshaw RA, Leslie FM (1990) Epidermal growth factor and basic fibroblast growth factor: effects on an overlapping population of neocortical neurons in vitro. Brain Res 535:255-263.

Kornbluth S, Paulson KE, Hanafusa H (1988) Novel tyrosine kinase identified by phosphotyrosine antibody screening of cDNA libraries. Mol Cell Biol 8:5541-5544.

Landon RM, Robbins RJ (1986) Somatostatin release from dissociated cerebral cortical cell cultures. Methods Enzymol 124:412-424.

Leber SM, Breedlove SM, Sanes JR (1990) Lineage, arrangement, and death of clonally related motoneurons in chick spinal cord. $J$ Neurosci 10:2451-2462.

Lee PL, Johnson DE, Cousens LS, Fried VA, Williams LT (1989) Purification and complementary DNA cloning of a rcceptor for basic fibroblast growth factor. Science 245:57-60.

Lendhal U, McKay RDG (1990) The use of cell lines in neurobiology. Trends Neurosci 13:132-137.

Liu L, Nicoll CS (1988) Evidence for a role of basic fibroblast growth factor in rat embryonic growth and differentiation. Endocrinology 123:2027-2031.

Luskin MB, Pearlman AL, Sanes JR (1988) Cell lineage in the cerebral cortex of the mouse studied in vivo and in vitro with a recombinant retrovirus. Neuron 1:635-647.

Luskin MB, Parnavelas JG, Barfield JA (1993) Neurons, astrocytes, and oligodendrocytes of the rat ccrebral cortex originate from separate progenitor cells: an ultrastructural analysis of clonally related cells. $\mathrm{J}$ Neurosci 13:1730-1750.

Magal E, Burnham P, Varon S (1991) Effects of ciliary neuronotrophic factor on rat spinal cord neurons in vitro: survival and expression of choline acetyltransferase and low-affinity nerve growth factor receptors. Dev Brain Res 63:141-150.

McManaman JL, Smith RJ, Appel SH (1985) Low molecular weight peptide stimulates cholinergic development in ventral spinal cord cultures. Dev Biol 112:248-252.

Morrison RS, Sharma A, de Vellis J, Bradshaw RA (1986) Basic fibroblast growth factor supports the survival of ecrebral cortical neurons in primary culture. Proc Natl Acad Sci USA 83:7537-7541.

Morrison RS, Kornblum HI, Leslie FM, Bradshaw RA (1987) Trophic stimulation of cultured neurons from neonatal rat brain by epidermal growth factor, Science 238:72-75.

Morrison RS, Keating RF, Moskal JR (1988) Basic fibroblast growth factor and epidermal growth factor exert differential trophic effects on CNS neurons. J Neurosci Res 21:71-79.

Murphy M, Drago J, Bartlett PF (1990) Fibroblast growth factor stimulates the proliferation and differentiation of neuronal precursor cells in vitro. J Neurosci Res 25:463-475.

Noble M, Murry K (1984) Purificd astrocytes promote the in vitro division of a bipotential glial progenitor cell. EMBO J 3:2243-2247.

Noble M, Murry K, Stroobant P, Waterfield MD, Riddle P (1988)
Platelet-derived growth factor promotes division and motility and inhibits premature differentiation of the oligodendrocyte/type-2 astrocyte progenitor cell. Nature 333:560-562.

Nornes HO, Das GD (1972) Temporal pattern of neurogenesis in spinal cord: cytoarchitecture and directed growth of axons. Proc Natl Acad Sci USA 69:1962-1966.

Nornes HO, Das GD (1974) Temporal pattern of neurogenesis in spinal cord of rat. I. An autoradiographic study-time and sites of origin and migration and settling patterns of neuroblasts. Brain Res $73: 121-138$

Ohashi T, Boggs S, Robbins P, Bahnson A, Patrene K, Wei F-S, Wei J-F, Li J, Lucht L, Fei Y, Clark S, Kimak M, He H, Mowery-Rushton $P$, Barranger JA (1992) Efficient transfer and sustained high expression of the human glucocerebrosidase gene in mice and their functional macrophages following transplantation of bone marrow transduced by a retroviral vector. Proc Natl Acad Sci USA 89:1133211336.

Oppenheim RW (1986) The absence of significant postnatal motoneuron death in the brachial and lumbar spinal cord of the rat. $J$ Comp Neurol 246:281-286.

Partanen J, Makela TP, Eerola E, Korhonen J, Hirvonen H, ClaessonWelsh L, Alitalo K (1991) FGFR-4, a novel acidic fibroblast growth factor receptor with a distinct expression pattern. EMBO J 10:13471354.

Perraud F, Besnard F, Pettmenn B, Sensenbrenner M, Labourdette G (1988) Effects of acidic and basic fibroblast growth factors (aFGF and $b F G F$ ) on the proliferation and the glutamine synthetase expression of rat astroblasts in culture. Glia 1:124-131.

Phelps PE, Barber RP, Vaughn JE (1988) Generation patterns of four groups of cholinergic neurons in rat cervical spinal cord: a combined tritiated thymidine autoradiographic and choline acetyltransferase immunocytochemical study. J Comp Neurol 273:459-472.

Price J, Thurlow L (1988) Cell lineage in the rat cerebral cortex: a study using retroviral-mediated gene transfer. Development 104:473482.

Price J, Turner D, Cepko C (1987) Lineage analysis in the vertebrate nervous system by retrovirus-mediated gene transfer. Proc Natl Acad Sci USA 84:156-160.

Raff MC (1989) Glial cell diversification in the rat optic nerve. Science 243:1450-1455.

Ray J, Peterson DA, Schinstine M, Gage FH (1993) Proliferation, differentiation and long-term culture of primary hippocampal neurons. Proc Natl Acad Sci USA 90:3602-3606.

Renfranz PJ, Cunningham MG, McKay RDG (1991) Region-specific differentiation of the hippocampal stem cell line HiB5 upon implantation into the developing mammalian brain. Cell 66:713-729.

Reynolds BA, Weiss S (1992) Generation of neurons and astrocytes from isolated cells of the adult mammalian central nervous system. Science 255:1707-1710.

Reynolds BA, Tetzlaff W, Weiss S (1992) A multipotent EGF-responsive striatal embryonic progenitor cell produccs neurons and astrocytes. J Neurosci 12:4565-4574.

Ryder EF, Snyder EY, Cepko CL (1989) Establishment and characterization of multipotent neural cell lines using retrovirus vectormediated oncogene transfer. J Neurobiol 21:356-375.

Sanes JR, Rubenstein JLR, Nicols J-F (1986) Use of a recombinant retrovirus to study post-implantation cell lineage in mouse embryos. EMBO J 5:3133-3142.

Sendtner M, Arakawa Y, Stockli KA, Kreutzberg GW, Thoenen H (1991) Effect of ciliary neurotrophic factor (CNTF) on motoneuron survival. J Cell Sci [Suppl] 15:103-109.

Smith RG, Appel SH (1983) Extracts of skeletal muscle increase neurite outgrowth and cholinergic activity of fetal rat spinal motor neurons. Science 219:1079-1081.

Snyder EY, Deitcher DL, Walsh C, Arnold-Aldea S, Hartweig EA, Cepko CL (1992) Multipotent neural cell lines can engraft and participate in development of mouse cerebellum. Cell 68:33-51.

Stemple DL, Anderson DJ (1992) Isolation of a stem cell for neurons and glia from the mammalian neural crest. Cell 71:973-985.

Walicke PA (1988) Basic and acidic fibroblast growth factors have trophic effects on neurons from multiple CNS regions. J Neurosci 8:2618-2627.

Walicke PA, Baird A (1988) Neurotrophic effects of basic and acidic fibroblast growth factors are not mediated through glia cells. Dev Brain Res 40:71-79. 
Walicke P, Cowan WM, Ueno N, Baird A, Guillemin R (1986) Fibroblast growth factor promotes survival of dissociated hippocampal neurons and enhances neurite extension. Proc Natl Acad Sci USA 83:3012-3016.

Walicke PA, Feige J-J, Baird A (1989) Characterization of the neuronal receptor for basic fibroblast growth factor and comparison to receptors on mesenchymal cells. J Biol Chem 264:4120-4126.

Wanaka A, Johnson EM, Milbrandt J (1990) Localization of FGF receptor $\mathrm{mRNA}$ in the adult rat central nervous system by in situ hybridization. Neuron 5:288-292.
Wanaka A, Milbrandt J, Johnson EM (1991) Expression of FGF receptor gene in rat development. Development 111:455-468.

Williams BP, Read J, Price J (1991) The generation of neurons and oligodendrocytes from a common precursor cell. Neuron 7:685-693.

Yan Q, Johnson EM (1988) An immunohistochemical study of the nerve growth factor (NGF) receptor in developing rats. J Neurosci 8:3481-3498. 